\title{
7. MORPHOLOGY, GEOCHEMISTRY, AND EVOLUTION OF SEROCKI VOLCANO ${ }^{1}$
}

\author{
Susan E. Humphris, ${ }^{2}$ Wilfred B. Bryan, ${ }^{2}$ Geoffrey Thompson, ${ }^{2}$ and Laurie K. Autio ${ }^{3}$
}

\begin{abstract}
Basalts collected during drilling and diving programs on Serocki Volcano mostly fall within a limited compositional range, and are moderately evolved, normal MORBs with distinctive high $\mathrm{MgO}$ contents (averaging $7.60 \mathrm{wt} \%$ ) and high $\mathrm{Al}_{2} \mathrm{O}_{3}$ concentrations (averaging $16.14 \mathrm{wt} \%$ in whole rock samples). However, samples recovered from within the central crater have lower $\mathrm{TiO}_{2}$ and $\mathrm{FeO} * \mathrm{MgO}$, and higher $\mathrm{MgO}$ and $\mathrm{Al}_{2} \mathrm{O}_{3}$ concentrations, and are most similar to glasses recovered at Site 649 about $45 \mathrm{~km}$ to the north. Comparison of the observed geochemical variations with low-pressure experimental work and other samples from the region suggests that the Serocki Volcano and Site 649 data are compatible with crystal-liquid fractionation involving both olivine and early-stage clinopyroxene, as well as plagioclase, and that the sources may be similar even though Sites 648 and 649 are located in different, but adjacent, spreading cells.

Consideration of the stratigraphy and morphology of Serocki Volcano suggests that this feature is more properly described as a megatumulus or lava delta, associated with a steeper, conical peak to the southwest. The evolution of Serocki Volcano involved early construction of a marginal rampart of pillows, followed by doming of this feature and the formation of a perched lava pond. Draining of this pond resulted in collapse and the formation of the central crater.
\end{abstract}

\section{INTRODUCTION}

The Mid-Atlantic Ridge south of the Kane Fracture Zone (to about $22^{\circ} \mathrm{N}$ ) is one of the most extensively studied segments of a slow-spreading accretionary lithosphere plate boundary (e.g., Miyashiro et al., 1969, 1970; Van Andel and Bowin, 1968; Melson et al., 1968; Purdy et al., 1978; Detrick and Purdy, 1980; Karson and Dick, 1983; Purdy and Detrick, 1986). More recently, several geophysical and geological investigations in the region have elucidated the large-scale structure of the rift valley (Detrick et al., 1984; Mayer et al., 1985; Karson et al., 1987; Brown and Karson, 1988; Kong et al., in press; Toomey et al., 1988) and have constrained the spreading history of the area over the last few million years (Schulz et al., in press). All these studies have indicated considerable along-strike morphologic and structural changes that can be related to the existence of at least two distinct spreading cells, which may be separated by a small or zerooffset transform fault located about $40 \mathrm{~km}$ south of the Kane Fracture Zone.

Serocki Volcano $\left(22^{\circ} 55^{\prime} \mathrm{N}, 44^{\circ} 57^{\prime} \mathrm{W}\right)$ is located in the southern spreading segment about $70 \mathrm{~km}$ south of the Kane Fracture Zone (Fig. 1). 'The drilling and diving programs during 1985 and 1986 have resulted in detailed observations of the morphology, stratigraphy, and geochemistry of this single constructional feature, and have provided the first threedimensional view of an axial volcano in the rift valley of the Mid-Atlantic Ridge. In this paper we synthesize the geophysical, morphologic, observational, and geochemical data collected on Serocki Volcano, and compare these data with those available for other dredged samples and drill sites in the area. These include Sites 395 and 396 drilled on DSDP Legs 45 and 46, and Sites 669 and 670 drilled on ODP Leg 109. The data are used to assess the construction and evolution of Serocki

\footnotetext{
${ }^{1}$ Detrick, R., Honnorez, J., Bryan, W. B., Juteau, T., et al., 1990. Proc. $O D P$, Sci. Results, 106/109: College Station, TX (Ocean Drilling Program).

${ }^{2}$ Woods Hole Oceanographic Institution, Woods Hole, MA 02543.

${ }^{3}$ Department of Geology and Geography, Morrill Science Center, University of Massachusetts, Amherst, MA 01003.
}

Volcano, and the implications for crustal accretion in this area are discussed.

\section{TECTONIC SETTING}

The morphology of the spreading cell in the southern part of the MARK area has been summarized most recently by Brown and Karson (1988) and Kong et al. (in press). The median valley is well-defined, with the western valley walls rising about $1200 \mathrm{~m}$ and the eastern valley walls having about $700 \mathrm{~m}$ of relief. Serocki Volcano is one of a band of small, volcano-like features that trends north-northeast $\left(010^{\circ}\right)$ from the axial high about $80 \mathrm{~km}$ south of the Kane Fracture Zone to converge with the eastern valley wall at about $23^{\circ} 15^{\prime} \mathrm{N}$. These volcano-like features are all circular in plan, with broad summit plateaus $50-200 \mathrm{~m}$ above the surrounding seafloor. Commonly, they have a depression or crater in the center of the plateau. SeaMARC I data suggest that these circular structures are superimposed on older, more fissured seafloor (Kong et al., in press). Because of their distinctive morphology, these circular structures stand out against the rougher, more irregular seafloor terrain in the SeaMARC imagery, and in plan view are suggestive of a set of small conical volcanoes with central craters.

The morphology of Serocki Volcano and its surroundings are shown in more detail in Figure 1 and in the threedimensional image based on digitized Sea Beam, SeaMARC I, and Alvin bathymetry (Fig. 2). Serocki is offset to the east side of a line of relatively steep conical peaks that lie on the $010^{\circ}$ trend. We interpret these peaks to be a set of extrusive lava cones following a $010^{\circ}$ fissure. Serocki Volcano is connected to the peak immediately to the south and west by a low ridge; a ridge at a similar elevation projects out a short distance on the east side of this peak. We interpret these ridges to be short flank lava flows that breached the base of this cone, and suggest that the northeast-trending ridge apparently became the established extrusive vent.

The flat summit plateau of Serocki Volcano is about $800 \mathrm{~m}$ in diameter, and stands about $60 \mathrm{~m}$ above the surrounding seafloor. It has a central crater about $200 \mathrm{~m}$ across (Fig. 2). 


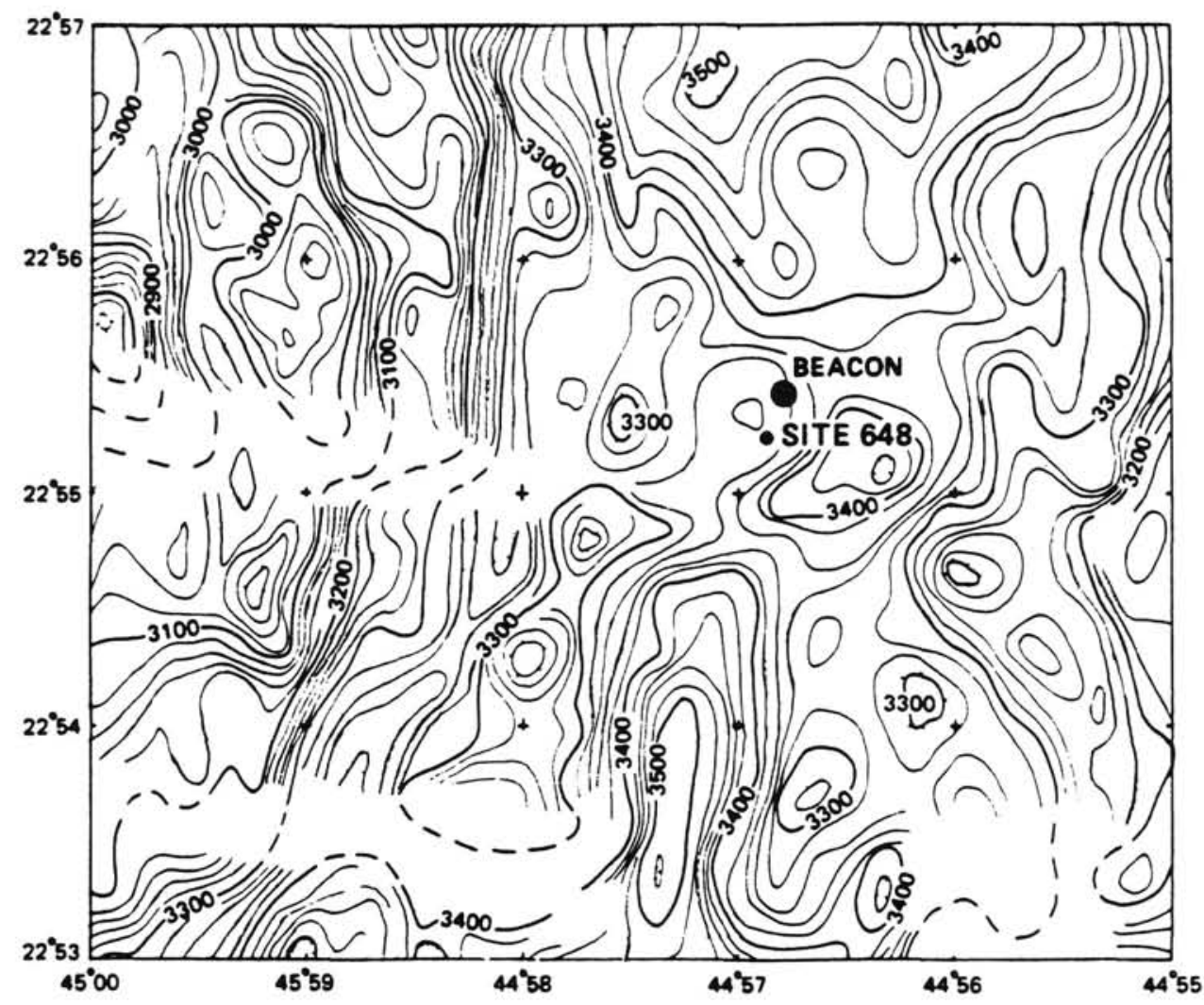

Figure 1. Detailed Sea Beam bathymetry map of the area around Site 648 . Contour interval is $10 \mathrm{~m}$.

Extensional tectonism has disrupted the western part of the plateau with a series of faults parallel to the rift valley (Mayer et al., 1985), and the eastern flank of Serocki Volcano is cut by an east-facing fault system.

The freshest rocks in the region (as indicated by photography and dredging) occur to the east-southeast of Serocki Volcano, but all exhibit some degree of weathering (Brown and Karson, in press). The pillow lavas of Serocki Volcano also show evidence of some hydration and weathering, and the summit plateau has a moderate sediment cover. This, together with the geophysical evidence from this area, suggests that this segment of the Mid-Atlantic Ridge may be in an extensional phase of tectonism with volcanic activity being limited to isolated eruptions of small axial volcanoes (Detrick et al., 1984).

\section{MORPHOLOGY OF SEROCKI VOLCANO}

\section{Surface Morphology}

Direct observations of the morphology of Serocki Volcano have been made from a camera survey and an Alvin transect. During Leg 106, a pre-drilling survey was carried out to identify the exact location for the drilling site. A low-light, high resolution camera that produced real-time video images was used to construct a geologic map (Fig. 3). During an expedition to the MARK area in June 1986, one Alvin dive was made on Serocki Volcano for detailed morphologic and structural observations, and to intensively sample surface features. The track of the Alvin and the sampling locations are shown in Figure 4.

The summit plateau is extremely flat with less than $5 \mathrm{~m}$ relief. It consists of bulbous and elongate pillows that are typically 1-2 $\mathrm{m}$ in diameter (Plate 1 ). Most of the lavas show delicate surface ornamentation of small fingers, buds, and rounded protrusions. The eastern scarp and crater walls are also composed almost entirely of pillows, although a few sheet flows are observed. In addition, a thin sheet flow crops out along the northeastern rim of the crater, although it is disrupted by fissures (Plate 1 , Fig. 4 ).

The summit plateau of Serocki Volcano is highly fissured (Plate 1, Fig. 5). These post-eruptive fissures are generally narrow, typically $1 \mathrm{~m}$ or less in width, and, although they follow the regional trend, many of the fissures bifurcate to trend north and north-northwest. Around the crater rim, a second set of radial fissures is well developed.

The sediment cover is moderate, but variable, on the summit plateau, and averages $0.5 \mathrm{~m}$ in thickness. Most of the pockets and cracks between pillows are filled with sediment, and the pillow tops vary from being exposed to being covered with a few centimeters of sediment. The eastern part of the summit plateau up to, and including, the sheet flows at the edge of the crater, shows an almost continuous sediment cover (Plate 1, Fig. 6). Serocki Volcano is one of the more heavily sedimented volcanic structures in this area, suggesting it may be several tens of thousands of years old (Karson et al., 1987).

\section{Stratigraphic Section}

Drilling at Site 648 during ODP Legs 106 and 109 penetrated the eastern side of the summit plateau to a depth of 50.5 $\mathrm{m}-$ not quite as deep as the bottom of the crater. Most of the basalt recovered represented cored rubble, although some more massive units were drilled near the bottom of the hole. All the material recovered consists of sparsely olivine-plagioclase phyric basalt that varies in the degree of crystallinity and vesicularity. Establishing a lithological sequence is extremely difficult because of repeated collapse of material into the hole. However, based on comparison of distinctive vesicular cores that constrained the depth and thickness of that unit, the Leg 


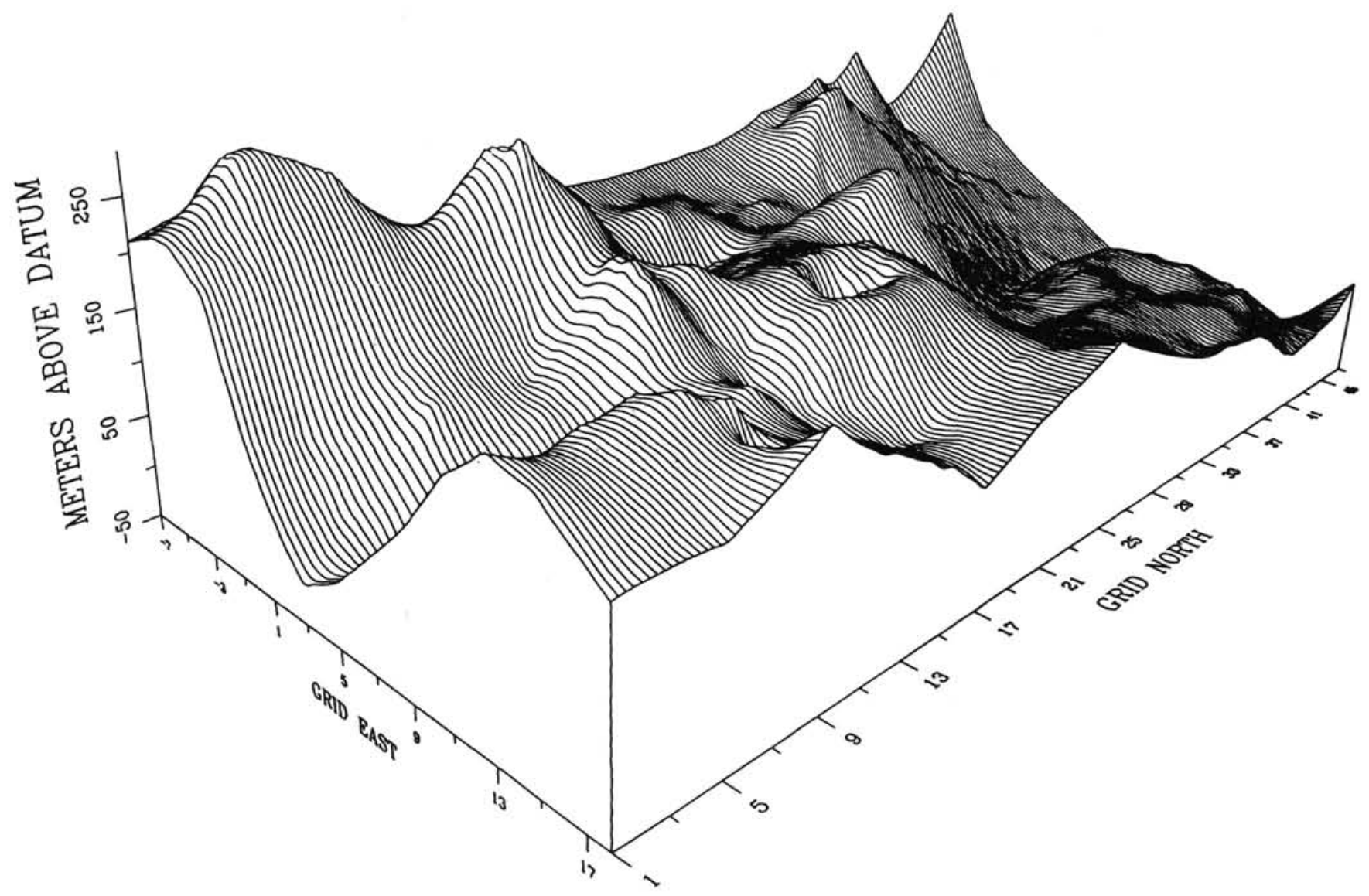

Figure 2. Three-dimensional view of Serocki Volcano and its environs constructed from available Sea Beam data.

109 Shipboard Scientific Party suggested the following stratigraphic succession: the top $30 \mathrm{~m}$ of Serocki Volcano consists of pillow lavas that are underlain by a $3-\mathrm{m}$ massive, aphanitic, vesicular basalt unit. This latter unit probably represents the quenched top of the underlying massive holocrystalline basalt that constitutes the lower $17.5 \mathrm{~m}$ of the hole.

During the Alvin dive, the eastern scarp of the volcano and its crater were also investigated and sampled. Although the lower part of the eastern scarp is obscured by a talus ramp that is $100-200 \mathrm{~m}$ wide, about $50 \mathrm{~m}$ of volcanic stratigraphy is exposed. The lowest unit observed consists of three or four thin flows, each less than $1 \mathrm{~m}$ in thickness. Above this level, the scarp is composed of a succession of pillow lavas (Plate 2, Fig. 3). The central crater is approximately $65 \mathrm{~m}$ deep, and broken sheet flows and pillow lavas are exposed on the crater floor (Plate 2, Fig. 1). All of the material is highly disrupted making it difficult to distinguish talus from in situ material. The crater walls are riddled with fissures and, although largely obscured by talus, they appear to be composed of pillow lavas (Plate 2, Fig. 2). Along the northeastern side of the crater rim, fissured sheet flows are also present.

Combining the Sea Beam and SeaMARC I data with the detailed observations of tectonic setting, surface morphology, and stratigraphy, a diagrammatic representation of Serocki Volcano has been created (Fig. 5). These scale drawings illustrate the low relief and broad, flat form of the volcano, and the cross-section summarizes the lithological succession deduced from both the drilling results and the observations from Alvin. The arcuate fissures and flow breaching the northeastern side of Serocki Volcano are based on interpretation of the SeaMARC imagery obtained during the site survey; these features were not observed directly from Alvin or by the drill-ship TV system.

\section{GEOCHEMISTRY OF SEROCKI VOLCANO}

Major and trace element analyses of whole-rock samples were completed at Woods Hole Oceanographic Institution and the University of Massachusetts, Amherst, by X-ray fluorescence. Major element concentrations were determined on rock powders fused with a lanthanum-bearing, lithium tetraborate-based flux to form a glass disc. Trace elements were analyzed after preparation of pressed pellets of crushed rock powders. All analyses were performed on a Philips AXS automated spectrometer at WHOI, or on a Siemens MRS 6OOMP or SRS-2 spectrometer at University of Massachusetts. These methods, together with data reduction techniques, have been described in detail in Schroeder et al. (1980) and Autio and Rhodes (1983). The results of the analyses for the drilled samples are presented in Table 1, and for the Alvin samples are listed in Table 2. Other XRF analyses completed at University of Massachusetts from Sites 669 and 670 are included in our regional discussion, and are given in Table 3.

Glass fragments from individual samples collected during Alvin dive 1690 were analyzed for major elements by T. O'Hearn using the microprobe at the Smithsonian Institution (Melson, 1977); these are reported in Table 4. Glasses recovered during drilling were sampled and analyzed by microprobe at Massachusetts Institute of Technology as part of the shipboard sampling program. These are presented in Detrick, Honnorez, Bryan, Juteau, et al. (1988) and will be included in the following discussion. 


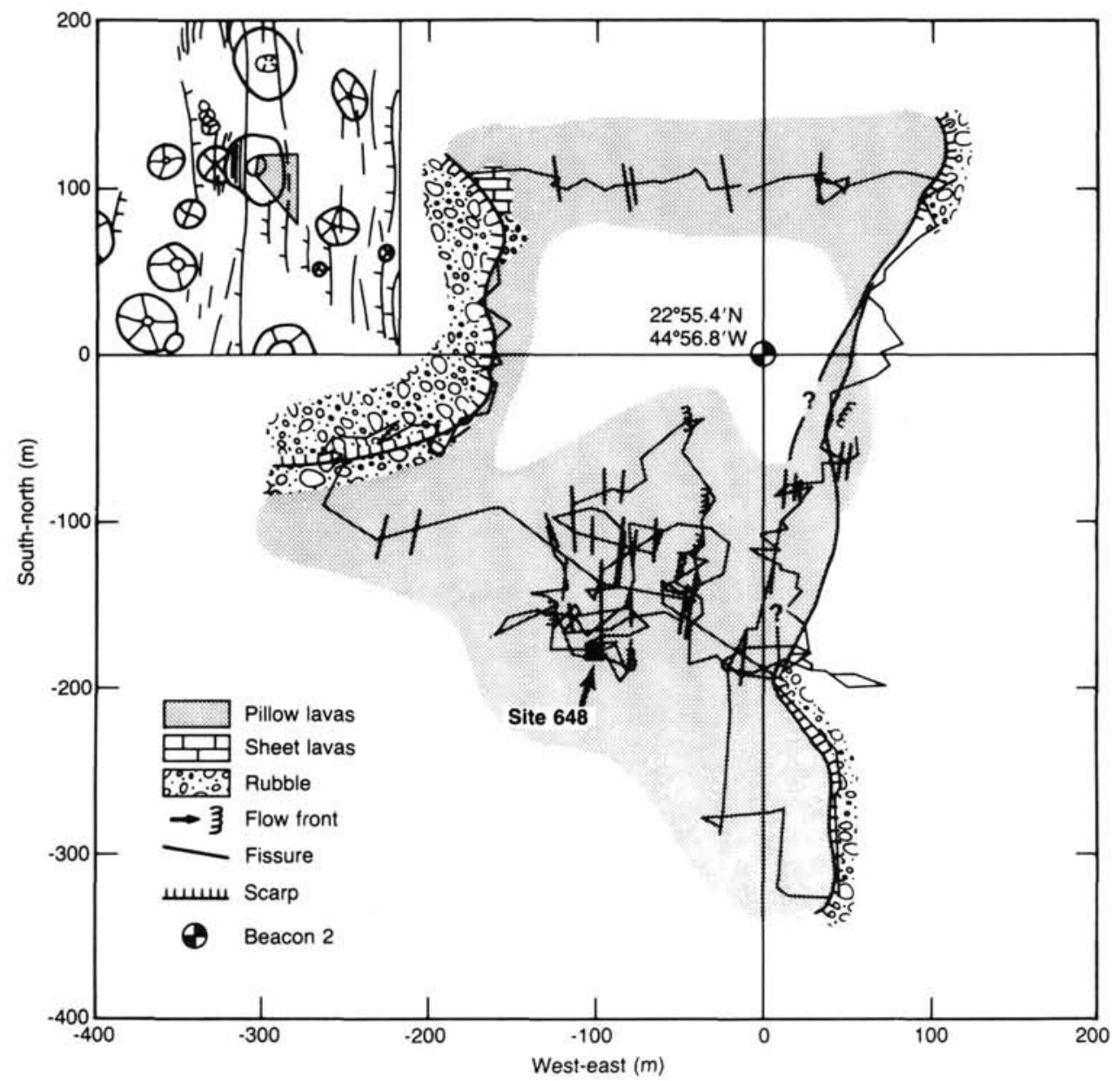

Figure 3. Geologic map of Serocki Volcano constructed by the Leg 106 shipboard scientific party from video-survey results. Inset shows tectonic interpretation of the area immediately surrounding Serocki Volcano, based on available Sea Beam and SeaMARC I data.

The glass and whole-rock analyses of the drilled material (Table 1) are notable for the limited range in composition throughout the hole, regardless of the textural changes within the stratigraphic sequence. They are all moderately-evolved, normal MORBs although their relatively high $\mathrm{MgO}$ contents (average of $7.60 \mathrm{wt} \%$ in both glasses and whole rocks) and high $\mathrm{Al}_{2} \mathrm{O}_{3}$ concentrations (averaging $15.76 \mathrm{wt} \%$ in the glasses and $16.14 \mathrm{wt} \%$ in the whole rocks) are distinctive; the regional significance of this will be discussed in a later section. The sparsely phyric nature of most of the basalts is reflected in the similarity between the glass and whole rock analyses. The minor differences observed in the $\mathrm{CaO}$ and $\mathrm{Al}_{2} \mathrm{O}_{3}$ concentrations between glass and whole-rock pairs can be attributed to variations in the abundance of plagioclase phenocrysts.

This compositional uniformity does not extend, however, to the samples collected from Alvin (Tables 2 and 4). Although many of them fall within the same narrow compositional range observed at Hole 648B, several of the samples indicate significant major and trace element variations within the volcanic pile of Serocki Volcano. This is illustrated in Figure 6 which shows variation diagrams for $\mathrm{TiO}_{2}$ and $\mathrm{Al}_{2} \mathrm{O}_{3}$ concentrations with $\mathrm{FeO} * / \mathrm{MgO}$ ratios in both glasses and whole-rock samples. For simplicity, the average compositions of Hole 648B glasses and whole rocks have been plotted for comparison. Most of the samples fall within a narrow compositional range, with $\mathrm{FeO}^{*} / \mathrm{MgO}$ varying between 1.24 and 1.42 ; this group includes both pillow lavas and the disrupted sheet flow located on the eastern rim of the crater (Alvin Sample 1690$15)$. However, the trend within this compositional range, and the presence of some more and less evolved samples, show evidence of a fractionation sequence; this is further depicted in the $\mathrm{Na}_{2} \mathrm{O}-\mathrm{FeO}^{*}-\mathrm{MgO}$ diagrams (Fig. 7). Alvin Sample $1690-5$ is the least evolved sample recovered from Serocki Volcano: it was collected from the base of the eastern scarp about $120 \mathrm{~m}$ below the summit plateau. This sample represents a basalt flow containing an estimated $10 \%$ of plagioclase phenocrysts ranging up to $5 \mathrm{~mm}$ in size. This accounts for the noticeably higher $\mathrm{CaO}, \mathrm{Al}_{2} \mathrm{O}_{3}$, and $\mathrm{Sr}$ concentrations in the whole rock analyses. Three other sparsely phyric samples similar to Alvin 1690-5 were all recovered from the crater. Alvin Sample $1690-17$ is a glassy pillow collected from the bottom of the crater, and Alvin Samples 1690-18A and B are pillow buds collected from the western wall of the crater about $20 \mathrm{~m}$ above the bottom. These glasses are low in $\mathrm{TiO}_{2}$ (average $1.45 \mathrm{wt} \%$ ) and $\mathrm{FeO}^{*} / \mathrm{MgO}(1.14)$ and high in $\mathrm{MgO}$ (average $7.97 \mathrm{wt} \%$ ) and $\mathrm{Al}_{2} \mathrm{O}_{3}$ (average $16.39 \mathrm{wt} \%$ ) concentrations relative to the Site 648 samples. They are most similar to glasses recovered at Site 649 located at the Snake Pit hydrothermal field at $23^{\circ} 22^{\prime} \mathrm{N}$ about $45 \mathrm{~km}$ north of Serocki Volcano, which also have low $\mathrm{TiO}_{2}$ (average $1.41 \mathrm{wt} \%$ ) and high $\mathrm{Al}_{2} \mathrm{O}_{3}$ (average $16.25 \mathrm{wt} \%$ ) contents, although Site 649 glasses have slightly lower $\mathrm{Zr}$ and $\mathrm{Y}$ concentrations. Their bulk rock compositions are very similar to sparsely phyric basalt rubble recovered at the top of Hole $670 \mathrm{~A}$ (Table 3). 


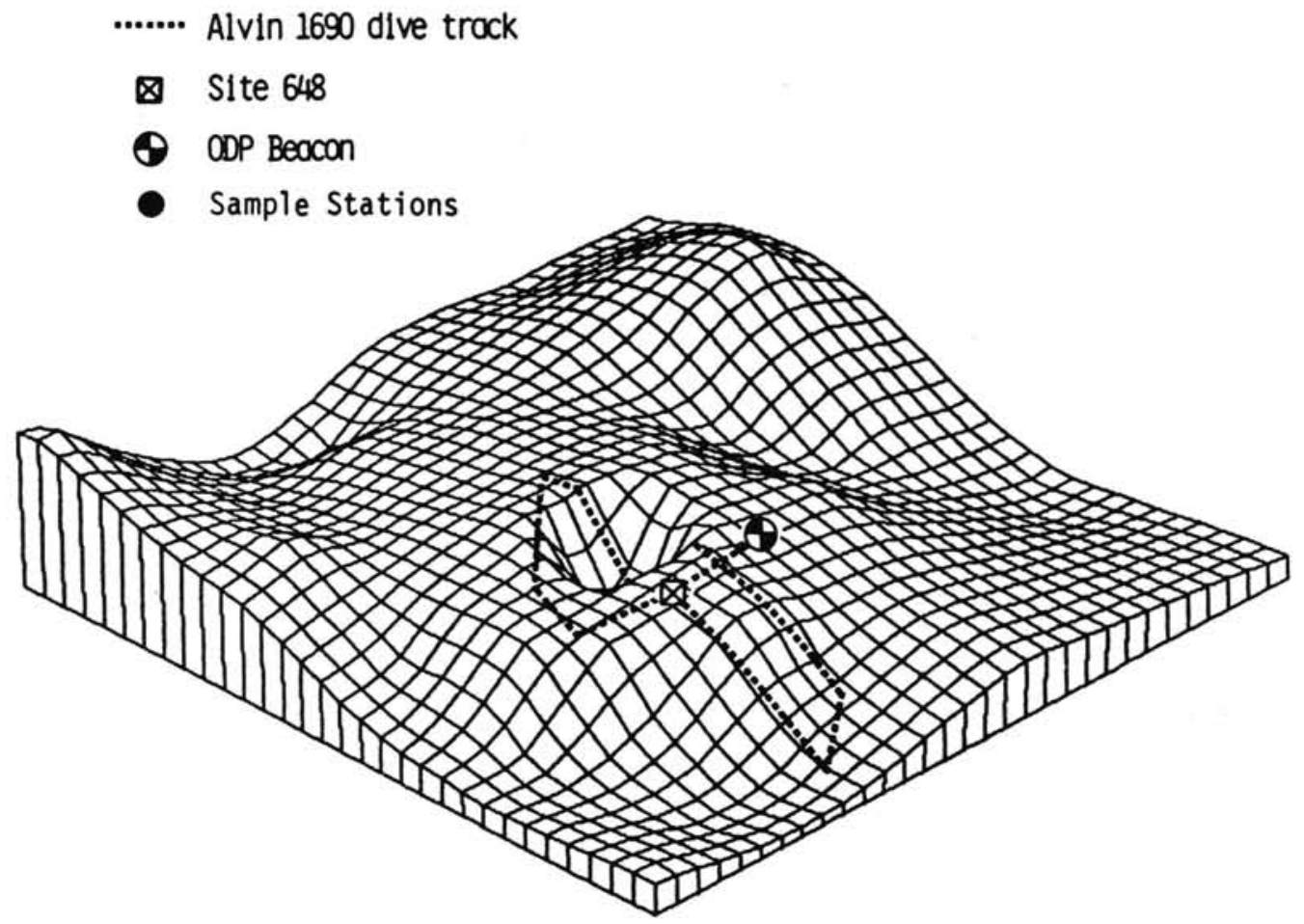

SEROCKI VOLCANO FROM SOUTHEAST

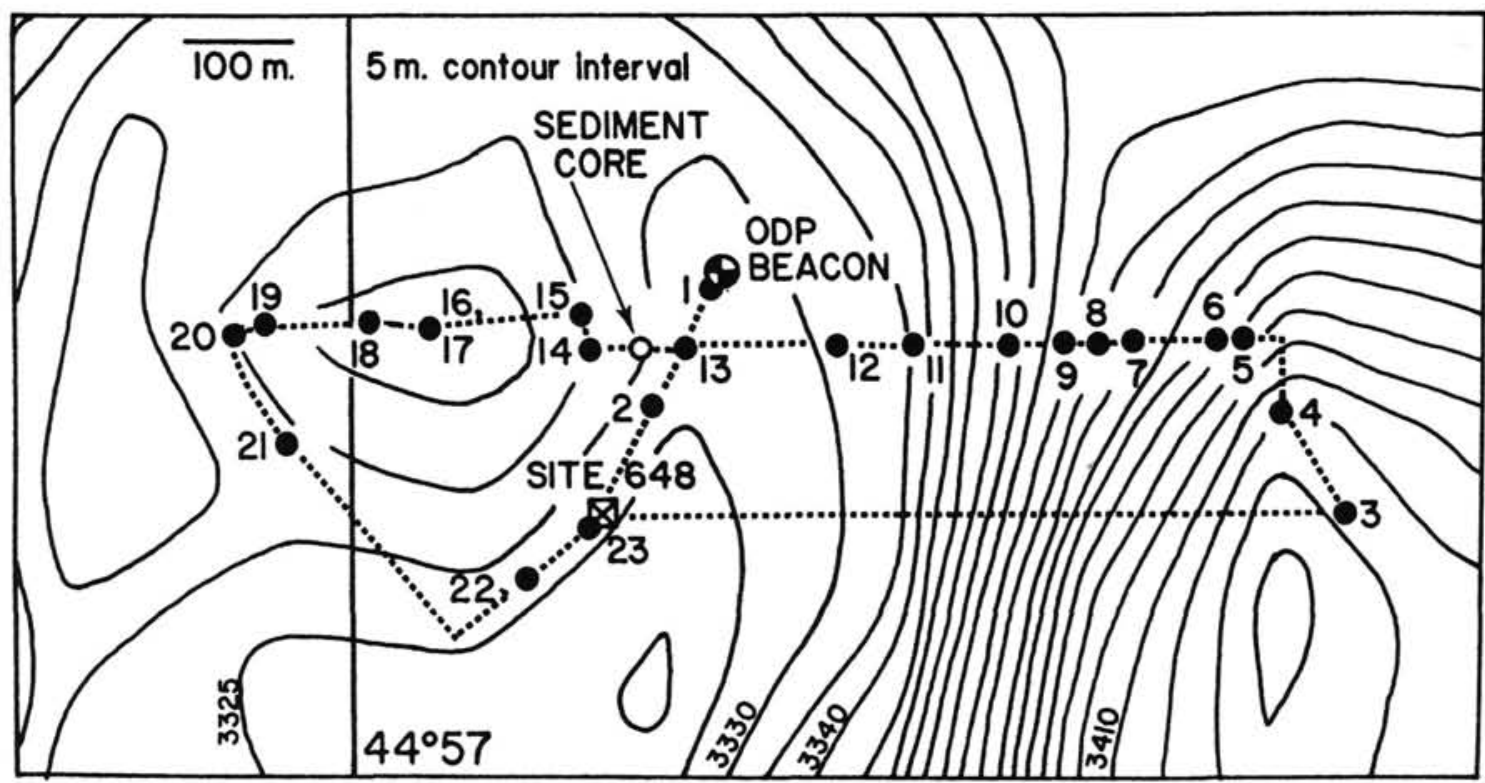

Figure 4. Track of Alvin Dive 1690 and the locations of the samples collected.

The glassy surface of a porphyritic basaltic flow (Alvin Sample 1690-16A) exhibits the most evolved composition, with an $\mathrm{FeO}^{*} / \mathrm{MgO}$ ratio of 1.59 and $\mathrm{a} \mathrm{TiO}_{2}$ content of 1.91 wt $\%$. This sample was recovered from the bottom of the crater in a region where distinction between talus and highly fractured in situ material was difficult. Its porphyritic nature, with an estimated $10 \%$ plagioclase and $1 \%$ olivine phenocrysts, results in the expected compositional differences between the glass and whole-rock analyses.
Selected trace elements provide an indication of the phases important in fractional crystallization. Plagioclase fractionation has been shown to have affected the major elements; it also affects the $\mathrm{Sr}$ concentrations in these rocks. Figure 8 illustrates the relations between the $\mathrm{Zr}$ concentrations and $\mathrm{Ni}$, $\mathrm{Cr}$, and $\mathrm{V}$ contents of the Alvin samples and the drilled samples analyzed at WHOI and at University of Massachusetts. In both the Alvin and drilled basalts, Ni decreases with increasing $\mathrm{Zr}$ content, although the trend is rather scattered: 

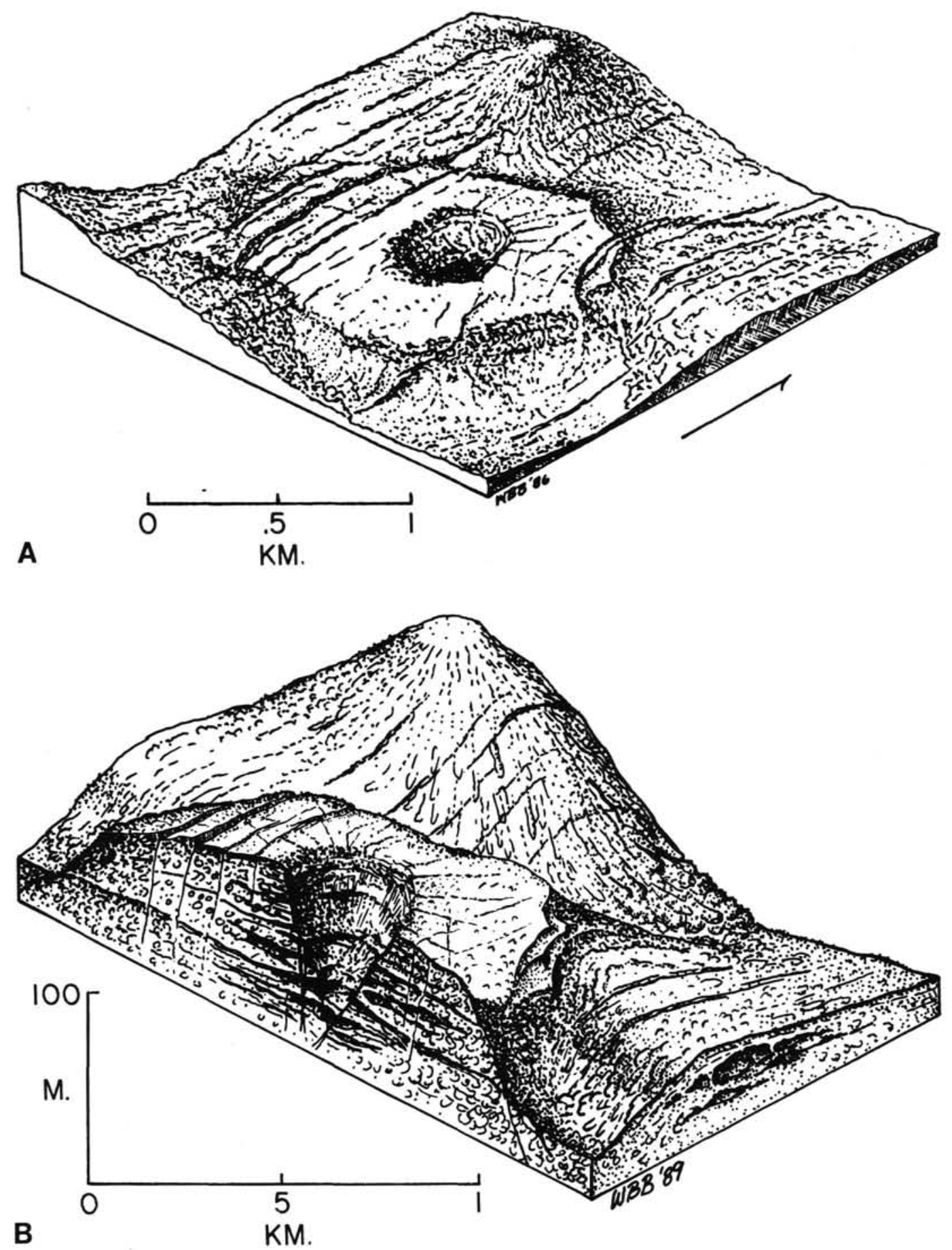

Figure 5. Artist's conception of Serocki Volcano. A. View of the volcano showing surface features and general morphology, based on Sea Beam, SeaMARC I, and Alvin observational data. B. Cross-section of the volcano showing stratigraphic sequence based on the drilling results and observational data from Alvin. Cavernous drain-away features were not directly observed but are an expected feature of a "megatumulus."

this suggests that olivine was a fractionating phase. Spinel is not present in these samples. The $\mathrm{Cr}$ content decreases from a level of about $280 \mathrm{ppm}$ in the least evolved samples to about $225 \mathrm{ppm}$ in the compositionally uniform group, suggesting that clinopyroxene may also have been an early-stage fractionating phase. However, V, which is also affected by clinopyroxene fractionation, shows a marked increase in concentration with increasing $\mathrm{Zr}$ content, suggesting that this may not have been as important as plagioclase or olivine. Alvin Sample 1690-5 shows depletion in all three of these trace elements due to dilution by the high abundance of plagioclase phenocrysts.

The incompatible element ratios are a useful distinction as they are sensitive to mantle source region composition, and show little or no change with fractional crystallization. Figure 9 shows variation diagrams for $\mathrm{TiO}_{2}$ and $\mathrm{Y}$ vs. $\mathrm{Zr}$ concentrations. The roughly linear trends indicate that, for both drilled 
and Alvin samples, the $\mathrm{Zr} / \mathrm{Y}$ and $\mathrm{Zr} / \mathrm{TiO}_{2}$ ratios are constant throughout the rock suite. This suggests that the rocks comprising Serocki Volcano originated from a single source, and that the observed major and trace element variations are the result of later fractionation processes. In addition, a MORB source is indicated by the high $\mathrm{Zr} / \mathrm{Nb}$ ratios $(>31)$ for these samples; the variations in this ratio are due to the analytical precision of $\mathrm{Nb}$ content determinations.

REE concentrations have been determined by ICP-OES at WHOI on selected drilled samples from Serocki Volcano, and the chondrite-normalized patterns are shown in Figure 10. They are all LREE-depleted, with $(\mathrm{La} / \mathrm{Sm})_{\mathrm{N}}$ ratios of $0.57-0.66$, indicative of an N-MORB source. They fall within a field of four samples from cruises AII92 and AII78 taken from the rift valley of the Mid-Atlantic Ridge at about $23^{\circ} \mathrm{N}$ (Bryan et al., 1981). This will be discussed more fully in the next section.

\section{REGIONAL GEOCHEMICAL COMPARISONS}

The most internally consistent data set for regional comparisons is the major element glass analyses, almost all of which were done at the Smithsonian Institution. A recent summary of the broad-scale regional relations of these glasses for the North Atlantic has been presented by Melson and O'Hearn (1979). Many of these same glass analyses from $22^{\circ}$ to $25^{\circ} \mathrm{N}$ were presented by Bryan et al. (1981) and were also discussed in a comparison of the FAMOUS, Kane, and Cayman glass data sets by Bryan and Dick (1982). The similarities and differences between the Leg 106 and 109 data sets relative to other DSDP and ODP drill sites and dredge or submersible samples from the $22^{\circ}-25^{\circ} \mathrm{N}$ area will be emphasized in these comparisons.

As a group, the $22^{\circ}-25^{\circ} \mathrm{N}$ basalts and basalt glasses (the Kane group of Bryan and Dick, 1982) are higher in $\mathrm{Na}_{2} \mathrm{O}$ and lower in $\mathrm{CaO}$, and generally higher in $\mathrm{TiO}_{2}$ and $\mathrm{FeO}^{*}$ compared with the extensive glass data set from the FAMOUS area. These chemical differences are reflected in lower clinopyroxene saturation and a shift of the glass "pseudocotectic" toward plagioclase (Bryan and Dick, 1982). This shift is even more pronounced in the Cayman glasses, which are even higher in $\mathrm{Na}_{2} \mathrm{O}, \mathrm{FeO}^{*}$, and $\mathrm{TiO}_{2}$ and lower in $\mathrm{CaO}$ than the Kane data. Bryan et al. (1981) clearly showed that the $22^{\circ}-25^{\circ} \mathrm{N}$ basalts can be considered as typical N-MORBs, while the FAMOUS and Cayman regions are generally composed of transitional MORBs, suggesting that there are distinct mantle sources for these different tectonic settings.

There are now considerable phase equilibria data for basalts from the $22^{\circ}-25^{\circ} \mathrm{N}$ area (Grove and Bryan, 1983; Toomey et al. 1987). These data generally support the phase equilibria inferred from the natural data sets, although it has been shown that there is a substantial difference among possible "parental" magmas in the amount of crystallization required to reach clinopyroxene saturation. One of the most unusual samples experimentally studied comes from the AII78 dredge traverse north and east of Serocki Volcano at about $23^{\circ} 10^{\prime} \mathrm{N}$. Bryan et al. (1981) showed that the low $\mathrm{Ti}$, high-Al "primitive" basalt recovered in this collection could not fractionate at low pressure to produce any of the typical "more evolved" basalts in the Kane area. Low pressure experiments on this sample have indeed shown that it is saturated only in olivine or olivine plus plagioclase until it has crystallized nearly $50 \%$; even at that point it is so close to undersaturation that further crystallization does little to move the residual liquids toward the field of moderately silicaenriched basalts that are most typical of the $22^{\circ}-25^{\circ} \mathrm{N}$ area (Toomey et al., 1987).
Experience with these samples suggested that $\mathrm{Al}_{2} \mathrm{O}_{3}$ and $\mathrm{TiO}_{2}$ might be good discriminants for regional comparisons. Figure 11 shows an $\mathrm{Al}_{2} \mathrm{O}_{3}-\mathrm{TiO}_{2}$ plot of the Alvin samples from Serocki, the samples recovered by drilling at Sites 648 and 649 , and the high- $\mathrm{Al}_{2} \mathrm{O}_{3}$ dredge samples from AII78. Most of the Alvin and Site 648 samples lie along the high- $\mathrm{Al}_{2} \mathrm{O}_{3}$ side of the regional $\left(22^{\circ}-25^{\circ} \mathrm{N}\right)$ data set. As noted previously, drilling at Site 648 failed to penetrate the low $\mathrm{TiO}_{2}$, high- $\mathrm{Al}_{2} \mathrm{O}_{3}$ unit sampled by Alvin at the deepest points in the crater and on the eastern scarp. In this projection (Fig. 11), this "deep unit" is very similar to the Site 649 glass. Most of the Alvin collection and all of the Site 648 drill samples most closely resemble the glasses from the AII92 dredge traverse in the valley axis at about $23^{\circ} 01^{\prime} \mathrm{N}$, only about $10 \mathrm{~km}$ north of Serocki Volcano.

The most $\mathrm{Al}_{2} \mathrm{O}_{3}$-rich samples from Sites 395 and 396 also resemble the Serocki data. The small dashed field represents data from Site 396 east of the median valley; these samples resemble the Site 649 glasses and the lowest unit from Serocki. This was recognized as a distinct chemical subgroup (G2) by Melson (1978). The rest of the Site 396 glasses lie within the field occupied by all glasses from Site 395 west of the rift valley. Both the Site 396 glasses and those from Site 395 are unlike the other glass groups from the area in that they define a trend with a positive slope in $\mathrm{Al}_{2} \mathrm{O}_{3}-\mathrm{TiO}_{2}$ space.

The large field outlined by a dotted line in Figure 11 encloses all other available glass data from dredge and submersible sampling at $22^{\circ}-25^{\circ} \mathrm{N}$. This group extends to much more "evolved" compositions than anything recovered from Serocki, although the evolved Alvin Sample 1690-16 approaches this region. This sample is very similar to the aphyric basalt recovered at Site 669 (Table 4) and is the "most evolved"' sample known from this part of the rift valley.

Figure 12 shows the AII78 samples, the Serocki Volcano data from Site 648 and the Alvin collection, and Site 649. These are compared in $\mathrm{Al}_{2} \mathrm{O}_{3}-\mathrm{TiO}_{2}$ space with three experimental glasses from Toomey et al. (1987) which represent the starting composition, an intermediate stage of crystallization, and an "evolved" liquid at clinopyroxene saturation at low pressure. The starting composition is the "primitive" AII78 basalt. This suggests that the difference between the "most primitive" group from the base of Serocki Volcano and Site 649 , and the "more evolved" group containing the rest of the Alvin and Site 649 data, are compatible with crystal-liquid fractionation along a "liquid line of descent" similar to the AII78 experiment. However, within each group, the trends are flatter than in the AII78 experiment. Figure 13 shows an ALFE diagram as described by Reid et al. (in press), and using the same data as in Figure 12. This diagram is designed to eliminate the effects of addition or removal of feldspar, and is therefore useful in assessing the effects of olivine and clinopyroxene on the path of magma evolution during basalt crystallization (Reid et al., in press). The Fe-factor is calculated as molar $\mathrm{FeO}^{*} /\left(\mathrm{FeO}^{*}+\mathrm{MgO}\right)$, where $\mathrm{FeO}^{*}$ has been reduced by the amount of $\mathrm{FeO}$ in ilmenite. The $\mathrm{Al}$-factor is $\left(\mathrm{Al}_{2} \mathrm{O}_{3}\right.$ $\left.\mathrm{CaO}^{*}-\mathrm{Na}_{2} \mathrm{O}-\mathrm{K}_{2} \mathrm{O}\right) /\left(\mathrm{FeO}^{*}+\mathrm{MgO}\right)$, where $\mathrm{CaO}^{*}$ has been reduced by the amount of $\mathrm{CaO}$ in apatite. Figure 13 illustrates that, compared with the AII78 experiments, the Site 649Serocki trend starts at a lower Al-factor, and that the lowest unit on Serocki Volcano is somewhat more Fe-rich than the Site 649 glass. Overall, the trend of the data is lower and flatter than the low-pressure experiment. This requires a fractionation scheme for the Site 649-Serocki data involving both olivine and early-stage clinopyroxene (Reid et al., in press). This would be consistent with the Cr-depletion discussed previously. However, the second "more evolved" group tends to parallel the clinopyroxene-free AII78 experimental trend. These observations suggest multiple fractionation 
Table 1. Major and trace element analyses of samples from Site 648 on Serocki Volcano.

\begin{tabular}{|c|c|c|c|c|c|c|c|c|c|c|c|c|c|c|c|}
\hline & $\begin{array}{c}648 \mathrm{~A} \\
1-1 \\
2-4 \mathrm{~cm}\end{array}$ & $\begin{array}{c}648 \mathrm{~B} \\
1-1 \\
17-23 \mathrm{~cm}\end{array}$ & $\begin{array}{c}648 \mathrm{~B} \\
1-1 \\
59-62 \mathrm{~cm}\end{array}$ & $\begin{array}{c}648 \mathrm{~B} \\
1-2 \\
37-40 \mathrm{~cm}\end{array}$ & $\begin{array}{c}648 \mathrm{~B} \\
1-2 \\
93-95 \mathrm{~cm}\end{array}$ & $\begin{array}{c}\text { 648B } \\
3-1 \\
31-34 \mathrm{~cm}\end{array}$ & $\begin{array}{c}648 \mathrm{~B} \\
3-1 \\
74-77 \mathrm{~cm}\end{array}$ & $\begin{array}{c}648 \mathrm{~B} \\
6-1 \\
61-64 \mathrm{~cm}\end{array}$ & $\begin{array}{c}648 \mathrm{~B} \\
6-1 \\
78-81 \mathrm{~cm}\end{array}$ & $\begin{array}{c}648 \mathrm{~B} \\
6-1 \\
130-135 \mathrm{~cm}\end{array}$ & $\begin{array}{c}648 \mathrm{~B} \\
6-1 \\
134-136 \mathrm{~cm}\end{array}$ & $\begin{array}{c}648 \mathrm{~B} \\
7-2 \\
23-28 \mathrm{~cm}\end{array}$ & $\begin{array}{c}648 \mathrm{~B} \\
8-1 \\
18-20 \mathrm{~cm}\end{array}$ & $\begin{array}{c}648 \mathrm{~B} \\
8-1 \\
102-105 \mathrm{~cm}\end{array}$ & $\begin{array}{c}648 \mathrm{~B} \\
9-1 \\
28-33 \mathrm{~cm}\end{array}$ \\
\hline $\mathrm{SiO}_{2}$ & 50.17 & 50.11 & 49.87 & 50.13 & 50.26 & 49.77 & 50.10 & 50.33 & 49.85 & 49.82 & 50.46 & 50.39 & 50.36 & 50.27 & 50.30 \\
\hline $\mathrm{TiO}_{2}$ & 1.80 & 1.75 & 1.74 & 1.76 & 1.68 & 1.67 & 1.70 & 1.67 & 1.73 & 1.67 & 1.72 & 1.67 & 1.67 & 1.67 & 1.66 \\
\hline $\mathrm{Al}_{2} \mathrm{O}_{3}$ & 15.62 & 15.92 & 16.10 & 15.91 & 16.13 & 16.24 & 16.20 & 16.17 & 15.92 & 16.13 & 15.94 & 16.28 & 16.27 & 16.18 & 16.25 \\
\hline $\mathrm{FeO}^{*}$ & 10.21 & 10.00 & 9.89 & 10.04 & 9.67 & 9.64 & 9.71 & 9.65 & 9.97 & 9.77 & 9.87 & 9.58 & 9.61 & 9.60 & 9.60 \\
\hline $\mathrm{MnO}$ & 0.18 & 0.18 & 0.18 & 0.18 & 0.17 & 0.17 & 0.18 & 0.17 & 0.18 & 0.18 & 0.18 & 0.17 & 0.17 & 0.17 & 0.17 \\
\hline $\mathrm{MgO}$ & 7.48 & 7.57 & 7.50 & 7.58 & 7.61 & 7.71 & 7.54 & 7.40 & 7.61 & 7.76 & 7.61 & 7.47 & 7.52 & 7.48 & 7.56 \\
\hline $\mathrm{CaO}$ & 11.16 & 11.21 & 11.29 & 11.21 & 11.19 & 11.18 & 11.28 & 11.28 & 11.26 & 11.19 & 11.34 & 11.35 & 11.35 & 11.30 & 11.30 \\
\hline $\mathrm{Na}_{2} \mathrm{O}$ & 2.77 & 2.81 & 2.82 & 2.90 & 2.98 & 2.86 & 2.83 & 2.97 & 2.83 & 2.86 & 3.01 & 3.01 & 2.99 & 2.89 & 2.99 \\
\hline $\mathrm{K}_{2} \mathrm{O}$ & 0.15 & 0.17 & 0.17 & 0.15 & 0.23 & 0.17 & 0.16 & 0.24 & 0.18 & 0.08 & 0.12 & 0.25 & 0.22 & 0.23 & 0.22 \\
\hline $\mathrm{P}_{2} \mathrm{O}_{5}$ & 0.17 & 0.17 & 0.18 & 0.18 & 0.17 & 0.18 & 0.17 & 0.17 & 0.17 & 0.18 & 0.17 & 0.17 & 0.17 & 0.17 & 0.17 \\
\hline Sum & 99.71 & 99.89 & 99.74 & 100.04 & 100.10 & 99.59 & 99.87 & 100.06 & 99.70 & 99.64 & 100.42 & 100.37 & 100.33 & 99.95 & 100.22 \\
\hline $\mathrm{Rb}$ & 1.5 & 2.2 & 2.4 & 0.6 & 1.3 & 1.8 & 2.4 & 1.5 & 4.1 & 1.7 & 0.4 & 1.6 & 1.1 & 2.1 & 1.6 \\
\hline $\mathrm{v}$ & 294 & 272 & 277 & 279 & 258 & 258 & 282 & 257 & 273 & 251 & 259 & 217 & 258 & 255 & 250 \\
\hline $\mathrm{Cr}$ & 231 & 211 & 217 & 222 & 236 & 213 & 225 & 243 & 210 & 185 & 222 & 233 & 236 & 233 & 230 \\
\hline Co & 45 & 45 & 42 & 43 & - & 44 & 44 & - & 43 & 42 & - & - & - & - & - \\
\hline $\mathrm{Ni}$ & 105 & 110 & 106 & 104 & 113 & 114 & 110 & 107 & 104 & 105 & 97 & 107 & 101 & 105 & 102 \\
\hline $\mathrm{Cu}$ & 64 & 56 & 66 & 67 & - & 62 & 65 & - & 55 & 63 & - & - & - & - & - \\
\hline $\mathrm{Zn}$ & 84 & 79 & 79 & 82 & 89 & 72 & 79 & 90 & 73 & 69 & 90 & 87 & 94 & 87 & 83 \\
\hline $\mathrm{Sr}$ & 140 & 143 & 143 & 141 & 139 & 145 & 142 & 139 & 144 & 148 & 139 & 140 & 139 & 140 & 139 \\
\hline $\mathrm{Y}$ & 42 & 42 & 41 & 42 & 35 & 41 & 40 & 35 & 41 & 40 & 36 & 34 & 35 & 35 & 34 \\
\hline $\mathrm{Zr}$ & 134 & 130 & 129 & 131 & 128 & 125 & 126 & 128 & 128 & 123 & 128 & 126 & 126 & 127 & 124 \\
\hline $\mathrm{Nb}$ & 3 & 3 & 4 & 4 & 3 & 4 & 3 & 3 & 4 & 4 & 3 & 3 & 3 & 3 & 3 \\
\hline $\mathrm{LAB}^{*}$ & 1 & 1 & 1 & 1 & 2 & 1 & 1 & 2 & 1 & 1 & 2 & 2 & 2 & 2 & 2 \\
\hline
\end{tabular}


Table 1 (continued).

\begin{tabular}{|c|c|c|c|c|c|c|c|c|c|c|c|c|c|c|c|}
\hline & \multirow{2}{*}{$\begin{array}{c}648 \mathrm{~B} \\
9-1 \\
62-66 \mathrm{~cm}\end{array}$} & \multirow{2}{*}{$\begin{array}{c}648 \mathrm{~B} \\
10-1 \\
15-20 \mathrm{~cm}\end{array}$} & \multirow{2}{*}{$\begin{array}{c}648 \mathrm{~B} \\
13-1 \\
4-6 \mathrm{~cm}\end{array}$} & \multirow{2}{*}{$\begin{array}{c}648 \mathrm{~B} \\
13-1 \\
31-34 \mathrm{~cm}\end{array}$} & \multirow{2}{*}{$\begin{array}{c}648 \mathrm{~B} \\
15 \mathrm{R}-1 \\
88-90 \mathrm{~cm}\end{array}$} & \multirow{2}{*}{$\begin{array}{c}648 \mathrm{~B} \\
15-1 \\
107-108 \mathrm{~cm}\end{array}$} & \multirow{2}{*}{$\begin{array}{c}648 \mathrm{~B} \\
16-1 \\
13-17 \mathrm{~cm}\end{array}$} & \multirow{2}{*}{$\begin{array}{c}648 \mathrm{~B} \\
16-1 \\
20-24 \mathrm{~cm}\end{array}$} & \multirow{2}{*}{$\begin{array}{c}648 \mathrm{~B} \\
16 \mathrm{R}-1 \\
88-90 \mathrm{~cm}\end{array}$} & \multirow{2}{*}{$\begin{array}{c}648 \mathrm{~B} \\
17-1 \\
2-4 \mathrm{~cm}\end{array}$} & \multirow{2}{*}{$\begin{array}{c}648 \mathrm{~B} \\
17-1 \\
30-32 \mathrm{~cm}\end{array}$} & \multirow{2}{*}{$\begin{array}{c}648 \mathrm{~B} \\
18-1 \\
32-34 \mathrm{~cm}\end{array}$} & \multirow{2}{*}{$\begin{array}{c}648 \mathrm{~B} \\
19-1 \\
5-7 \mathrm{~cm}\end{array}$} & \multicolumn{2}{|c|}{ Hole 648B } \\
\hline & & & & & & & & & & & & & & $\bar{x}$ & $\sigma$ \\
\hline $\mathrm{SiO}_{2}$ & 50.20 & 50.16 & 50.47 & 50.69 & 50.11 & 50.17 & 50.15 & 50.27 & 50.29 & 50.31 & 50.27 & 50.59 & 50.40 & 50.22 & $(0.22)$ \\
\hline $\mathrm{TiO}_{2}$ & 1.68 & 1.66 & 1.68 & 1.67 & 1.60 & 1.68 & 1.67 & 1.66 & 1.60 & 1.67 & 1.67 & 1.72 & 1.66 & 1.68 & $(0.04)$ \\
\hline $\mathrm{Al}_{2} \mathrm{O}_{2}$ & 15.98 & 16.23 & 16.24 & 16.14 & 16.32 & 16.06 & 16.02 & 16.23 & 16.41 & 16.29 & 16.13 & 15.96 & 16.22 & 16.14 & $(0.14)$ \\
\hline $\mathrm{FeO}^{*}$ & 9.69 & 9.56 & 9.66 & 9.64 & 9.43 & 9.59 & 9.67 & 9.58 & 9.45 & 9.61 & 9.64 & 9.90 & 9.69 & 9.69 & $(0.16)$ \\
\hline $\mathrm{MnO}$ & 0.18 & 0.18 & 0.17 & 0.17 & 0.17 & 0.17 & 0.18 & 0.18 & 0.17 & 0.17 & 0.17 & 0.18 & 0.18 & 0.17 & $(0.01)$ \\
\hline $\mathrm{MgO}$ & 7.56 & 7.42 & 7.57 & 7.55 & 7.88 & 7.53 & 7.70 & 7.59 & 7.98 & 7.57 & 7.69 & 7.69 & 7.64 & 7.60 & (0.13) \\
\hline $\mathrm{CaO}$ & 11.25 & 11.31 & 11.32 & 11.28 & 11.25 & 11.26 & 11.25 & 11.28 & 11.25 & 11.30 & 11.22 & 11.28 & 11.31 & 11.27 & $(0.05)$ \\
\hline $\mathrm{Na}_{2} \mathrm{O}$ & 2.96 & 2.95 & 2.95 & 2.95 & 2.96 & 2.93 & 2.96 & 2.98 & 2.96 & 3.03 & 3.02 & 2.98 & 2.96 & 2.94 & $(0.07)$ \\
\hline $\mathrm{K}_{2} \mathrm{O}$ & 0.16 & 0.24 & 0.22 & 0.21 & 0.13 & 0.24 & 0.15 & 0.16 & 0.13 & 0.13 & 0.15 & 0.22 & 0.16 & 0.18 & $(0.05)$ \\
\hline $\mathrm{P}_{2} \mathrm{O}_{5}$ & 0.17 & 0.17 & 0.17 & 0.17 & 0.16 & 0.17 & 0.17 & 0.17 & 0.17 & 0.17 & 0.17 & 0.17 & 0.17 & 0.17 & $(0.01)$ \\
\hline Sum & 99.82 & 99.87 & 100.46 & 100.47 & 100.01 & 99.80 & 99.91 & 100.09 & 100.40 & 100.25 & 100.13 & 100.70 & 100.40 & 100.06 & \\
\hline $\mathrm{Rb}$ & 1.2 & 1.7 & 2.2 & 0.6 & - & 2.7 & 1.5 & 1.8 & - & 0.9 & 0.8 & 2.8 & 1.8 & 1.7 & $(0.80)$ \\
\hline V & 265 & 254 & 267 & 268 & - & 263 & 254 & 254 & - & 273 & 275 & 241 & 245 & 262 & (15) \\
\hline $\mathrm{Cr}$ & 248 & 228 & 248 & 249 & - & 235 & 228 & 230 & - & 247 & 255 & 211 & 213 & 228 & (16) \\
\hline Co & - & - & - & - & - & - & - & - & - & - & - & - & - & 44 & (2) \\
\hline $\mathrm{Ni}$ & 104 & 111 & 106 & 108 & - & 105 & 113 & 110 & - & 102 & 112 & 101 & 98 & 106 & (6) \\
\hline $\mathrm{Cu}$ & - & - & - & - & - & - & - & - & - & - & - & - & - & 62 & (4) \\
\hline $\mathrm{Zn}$ & 90 & 92 & 94 & 94 & - & 98 & 91 & 89 & - & 94 & 97 & 84 & 82 & 86 & (8) \\
\hline $\mathrm{Sr}$ & 138 & 140 & 137 & 138 & - & 138 & 139 & 140 & - & 139 & 138 & 141 & 142 & 140 & (3) \\
\hline Y & 35 & 35 & 35 & 35 & - & 35 & 35 & 34 & - & 35 & 35 & 36 & 34 & 37 & (3) \\
\hline $\mathrm{Zr}$ & 128 & 128 & 128 & 129 & - & 129 & 127 & 124 & - & 128 & 130 & 129 & 128 & 128 & (2) \\
\hline $\mathrm{Nb}$ & 3 & 4 & 4 & 4 & - & 4 & 4 & 3 & - & 4 & 5 & 3 & 4 & 4 & (1) \\
\hline LAB $^{*}$ & 2 & 2 & 2 & 2 & 2 & 2 & 2 & 2 & 2 & 2 & 2 & 2 & 2 & & \\
\hline
\end{tabular}

${ }_{1}^{1}$ Analyzed at Woods Hole Oceanographic Institution.

Analyzed at University of Massachusetts. 
Table 2. Major and trace element analyses of samples from Alvin dive 1690 on Serocki Volcano. All analyses completed at WHOI; sample locations in Figure 4. Major element analyses as wt\%; trace element concentrations in ppm.

\begin{tabular}{|c|c|c|c|c|c|c|c|c|c|c|c|c|}
\hline & $1690-1$ & $1690-2$ & $1690-3$ & $1690-4$ & $1690-5$ & $1690-6$ & $1690-7$ & $1690-8$ & $1690-9$ & $1690-10$ & $1690-11$ & $1690-12$ \\
\hline $\mathrm{SiO}_{2}$ & 50.12 & 50.29 & 50.47 & 50.29 & 48.94 & 49.96 & 50.02 & 50.08 & 50.16 & 50.24 & 50.08 & 49.92 \\
\hline $\mathrm{TiO}_{2}$ & 1.74 & 1.69 & 1.68 & 1.70 & 1.07 & 1.68 & 1.55 & 1.59 & 1.66 & 1.70 & 1.69 & 1.69 \\
\hline $\mathrm{FeO}^{*}$ & 9.94 & 9.81 & 9.75 & 9.83 & 6.65 & 9.76 & 9.14 & 9.46 & 9.65 & 9.78 & 9.79 & 9.80 \\
\hline $\mathrm{MnO}$ & - & 0.18 & 0.18 & - & - & 0.18 & 0.16 & 0.17 & 0.18 & - & 0.18 & - \\
\hline $\mathrm{MgO}$ & 7.64 & 7.28 & 7.31 & 7.55 & 6.52 & 7.23 & 7.03 & 7.31 & 7.40 & 7.64 & 7.37 & 7.18 \\
\hline $\mathrm{CaO}$ & 11.20 & 11.19 & 11.24 & 11.31 & 12.74 & 11.31 & 11.68 & 11.46 & 11.39 & 11.21 & 11.26 & 11.32 \\
\hline $\mathrm{K}_{2} \mathrm{O}$ & 0.11 & 0.10 & 0.11 & 0.11 & 0.14 & 0.15 & 0.13 & 0.16 & 0.16 & 0.11 & 0.20 & 0.10 \\
\hline $\mathrm{P}_{2} \mathrm{O}_{5}$ & 0.18 & 0.20 & 0.21 & 0.16 & 0.10 & 0.21 & 0.20 & 0.20 & 0.20 & 0.18 & 0.20 & 0.22 \\
\hline Sum & 99.57 & 99.42 & 99.66 & 100.02 & 99.34 & 99.22 & 99.20 & 99.31 & 99.69 & 99.75 & 99.43 & 99.25 \\
\hline $\mathrm{Rb}$ & 3 & 3 & 3 & 2 & 5 & 3 & 2 & 2 & 2 & 2 & 3 & 3 \\
\hline V & 285 & 281 & 272 & 278 & 180 & 268 & 255 & 263 & 265 & 280 & 269 & 277 \\
\hline $\mathrm{Cr}$ & 227 & 220 & 222 & 217 & 209 & 227 & 227 & 234 & 226 & 230 & 215 & 224 \\
\hline $\mathrm{Ni}$ & 111 & 111 & 110 & 111 & 99 & 110 & 115 & 108 & 107 & 108 & 107 & 111 \\
\hline $\mathrm{Cu}$ & 65 & 55 & 64 & 56 & 54 & 65 & 60 & 64 & 66 & 65 & 58 & 65 \\
\hline $\mathrm{Zn}$ & 79 & 79 & 78 & 78 & 48 & 77 & 69 & 75 & 77 & 79 & 76 & 80 \\
\hline $\mathrm{Sr}$ & 141 & 144 & 145 & 145 & 162 & 144 & 146 & 144 & 145 & 142 & 145 & 143 \\
\hline $\mathrm{Y}$ & 41 & 40 & 40 & 40 & 25 & 40 & 38 & 39 & 42 & 40 & 41 & 40 \\
\hline $\mathrm{Zr}$ & 131 & 132 & 132 & 129 & 86 & 132 & 119 & 124 & 131 & 128 & 133 & 133 \\
\hline $\mathrm{Nb}$ & 2 & 2 & 2 & 2 & 3 & 2 & 2 & 3 & 2 & 2 & 2 & 2 \\
\hline
\end{tabular}

paths, perhaps at different pressures, or complications due to mixing. Other evidence for these processes is discussed by Meyer and Shibata (this volume) and Grove et al. (this volume).

In summary, the samples recovered during Legs 106 and 109 from Serocki Volcano and the Snake Pit area conform to a high- $\mathrm{Al}_{2} \mathrm{O}_{3}$ magma type that has been relatively sparsely sampled on previous cruises and drilling legs. The Site 649 glass and the lowest unit sampled by Alvin at Serocki Volcano are very similar to the low $\mathrm{TiO}_{2}$, high- $\mathrm{Al}_{2} \mathrm{O}_{3}$ glass recovered at Site 396 (Unit G2 of Melson, 1978). Not surprisingly, the remainder of the Serocki glasses are most like the dredged glasses recovered by AII92 only a short distance north of Serocki volcano on the extension of the same rift system.

The Site 670 peridotites (Table 4) are discussed in detail elsewhere in this volume, so we will comment on them only briefly here. To date, most discussions of regional peridotite variations have been based on mineralogy not on bulk rock chemistry. Modal analyses of these peridotites (Komor and Grove, this volume) show clinopyroxene contents of $2 \%-5 \%$ by volume, consistent with other peridotites from the Kane Fracture Zone considered to represent mantle source rocks for this area. The analyzed samples in Table 4 average more than $50 \%$ serpentinization, so may not be valid indicators of true, fresh peridotite compositions. Compared with the average analysis of serpentinized peridotite from Site 395 (Natland et al., 1978), most of those from Site 670 are somewhat higher in $\mathrm{Al}_{2} \mathrm{O}_{3}$, and lower in total $\mathrm{FeO}$ and $\mathrm{CaO}$, although differences are not large.

\section{EVOLUTION OF SEROCKI VOLCANO AND IMPLICATIONS FOR VOLCANISM IN THIS REGION}

\section{Comparison to Subaerial Volcanoes}

We have followed the practice of the site survey reports and other contributions to this volume by referring to the Serocki structure as a "volcano." However, detailed consideration of the gross size, morphology, internal stratigraphy, and relation to surrounding volcanic structures, suggests that
Serocki is more properly described as a megatumulus or collapsed lava delta. Such features are commonly associated with tube-fed pahoehoe flows, but have not been extensively described in the literature. There is also a morphologic similarity to small lava shields with perched lava ponds that have been observed in Hawaiian eruptions (Holcomb et al., 1974). Some of these form directly above a major volcanic eruptive center, as in the case of Halemaumau, while others, like Mauna Ulu, grow over a fissure system fed from the main center. Volcanic tumuli and megatumuli typically develop on lava flows toward the downstream end of an active feeder tube. Following collapse or solidification of part of the tube, fluid overpressure ruptures the roof of the tube a short distance upstream from the blockage, and lava piles up above the tube. Growth of the pile may be exogenous, due to successive thin flows or stacking of lava tubes, or endogenous due to internal expansion and stretching of the outer shell of the structure. If the lava feed continues vigorously, the tumulus may broaden considerably and develop a flattened summit profile. The flanks are typically a rampart built up of stacked pahoehoe lava tubes, which enclose a growing pond of lava. The flattened summit consists of the quenched upper surface of the lava pond.

An excellent description of megatumuli on Mt. Etna has been given by Guest et al. (1984). The largest of these, Monte Callabasso, is about $1 \mathrm{~km}$ in diameter. It stands about $30 \mathrm{~m}$ above the adjacent surface on its uphill side and is $300 \mathrm{~m}$ high on the downslope side, so compares closely in size to the Serocki "volcano." This megatumulus is located above the lower end of the tube system feeding a lobe of one of the pahoehoe flows of the 1614-1624 system, where it would have been subjected to maximum fluid pressure from lava upstream in the tube (Guest et al., 1984).

The flows of 1614-1624 also were characterized by deltalike terraces, which gives them a stepped profile. Individual terraces may be up to $300 \mathrm{~m}$ in length and width, and 10-20 $\mathrm{m}$ in height at their fronts. These terraces developed as flows that were dammed behind their own solidifying fronts as they reached surfaces of relatively lower slope. Magmatic overpressure caused the growth of tumuli on the upper 
Table 2 (continued).

\begin{tabular}{|c|c|c|c|c|c|c|c|c|c|c|c|}
\hline & $1690-13$ & $1690-14$ & $1690-15$ & $1690-16 \mathrm{~A}$ & $1690-16 \mathrm{~B}$ & $1690-17$ & $1690-18 \mathrm{~A}$ & $1690-19$ & $1690-20$ & $1690-21$ & $1690-23$ \\
\hline $\mathrm{SiO}_{2}$ & 50.22 & 50.24 & 50.05 & 49.43 & 50.06 & 50.02 & 50.24 & 50.14 & 50.15 & 50.03 & 50.06 \\
\hline $\mathrm{TiO}_{2}$ & 1.71 & 1.70 & 1.75 & 1.44 & 1.55 & 1.45 & 1.46 & 1.55 & 1.72 & 1.52 & 1.72 \\
\hline $\mathrm{Al}_{2} \mathrm{O}_{3}$ & 15.99 & 15.91 & 15.93 & 17.38 & 16.72 & 16.00 & 16.09 & 16.03 & 16.02 & 16.23 & 15.91 \\
\hline $\mathrm{FeO}^{*}$ & 9.97 & 9.87 & 9.97 & 9.00 & 9.31 & 9.13 & 9.13 & 9.30 & 9.86 & 9.28 & 9.88 \\
\hline $\mathrm{MnO}$ & - & 0.18 & - & - & 0.17 & 0.17 & - & 0.17 & - & 0.17 & - \\
\hline $\mathrm{MgO}$ & 7.27 & 7.47 & 7.58 & 7.55 & 7.17 & 7.68 & 7.89 & 7.26 & 7.64 & 7.47 & 7.73 \\
\hline $\mathrm{CaO}$ & 11.25 & 11.24 & 11.23 & 11.17 & 11.27 & 11.62 & 11.51 & 11.52 & 11.20 & 11.57 & 11.18 \\
\hline $\mathrm{Na}_{2} \mathrm{O}$ & 2.95 & 2.86 & 2.87 & 2.78 & 2.85 & 2.72 & 2.74 & 2.79 & 2.91 & 2.87 & 2.82 \\
\hline $\mathrm{K}_{2} \mathrm{O}$ & 0.09 & 0.11 & 0.11 & 0.08 & 0.10 & 0.10 & 0.09 & 0.14 & 0.10 & 0.12 & 0.11 \\
\hline $\mathrm{P}_{2} \mathrm{O}_{5}$ & 0.21 & 0.21 & 0.17 & 0.22 & 0.21 & 0.20 & 0.20 & 0.21 & 0.18 & 0.19 & 0.18 \\
\hline Sum & 99.66 & 99.79 & 99.66 & 99.05 & 99.41 & 99.09 & 99.35 & 99.11 & 99.78 & 99.45 & 99.59 \\
\hline $\mathrm{Rb}$ & 3 & 1 & 2 & 2 & 1 & 2 & 3 & 1 & 2 & 3 & 2 \\
\hline V & 289 & 276 & 283 & 237 & 245 & 251 & 261 & 252 & 280 & 257 & 278 \\
\hline $\mathrm{Cr}$ & 225 & 224 & 220 & 288 & 3023 & 272 & 284 & 240 & 223 & 249 & 221 \\
\hline Co & 45 & 44 & 44 & 44 & 42 & 45 & 44 & 43 & 44 & 44 & 43 \\
\hline $\mathrm{Ni}$ & 114 & 113 & 110 & 120 & 106 & 123 & 119 & 114 & 109 & 114 & 114 \\
\hline $\mathrm{Cu}$ & 59 & 63 & 57 & 60 & 61 & 62 & 70 & 65 & 63 & 69 & 63 \\
\hline $\mathrm{Zn}$ & 80 & 80 & 79 & 70 & 73 & 71 & 71 & 72 & 79 & 73 & 79 \\
\hline $\mathrm{Sr}$ & 142 & 143 & 142 & 151 & 148 & 146 & 143 & 147 & 142 & 148 & 142 \\
\hline $\mathrm{Y}$ & 41 & 41 & 40 & 34 & 37 & 34 & 35 & 38 & 40 & 37 & 40 \\
\hline $\mathrm{Zr}$ & 135 & 134 & 131 & 116 & 123 & 112 & 112 & 120 & 130 & 119 & 130 \\
\hline $\mathrm{Nb}$ & 2 & 2 & 2 & 3 & 3 & 3 & 1 & 2 & 2 & 3 & 2 \\
\hline
\end{tabular}

surfaces and especially on the fronts of the terraces. Terraces grew in size, until lava ponded behind the dam made a path around the dam or broke through it. This process was repeated numerous times at successively lower levels (Guest et al., 1984).

Central collapse is not a major feature of the megatumuli and terraces described by Guest et al. (1984). In this respect, Serocki more closely resembles Mauna Ulu on the east rift of Kilauea Volcano in Hawaii. Mauna Ulu rises about $125 \mathrm{~m}$ above the surrounding area. It has a broad, shield-like profile with a maximum diameter of about $2 \mathrm{~km}$. During certain phases of activity the summit contained an elongated perched lava lake several hundred meters wide while, at other times, drainage and collapse left a summit crater up to $200 \mathrm{~m}$ deep (Holcomb et al., 1974).

\section{A Conceptual Model for Growth and Evolution of Serocki}

The evolution of Serocki can be understood by considering our morphologic and stratigraphic observations in the context of these well-documented subaerial volcanic landforms. As shown in Figures 1 and 2, Serocki is a sub-circular, delta-like form connected to the northeast flank of a steeper, conical peak to the southwest by a short ridge. This conical peak is one of four aligned about $\mathrm{N} 10^{\circ} \mathrm{E}$; we interpret these as exogenous lava cones that define the main eruptive fissure in this area. Serocki thus appears initially to have been a lava delta confined between the tumulus ridge and another ridge to the east. A perched lava pond within the summit area accounts for the gently sloping upper plateau. Direct evidence for the lava pond remains in the remnants of sheet flows observed at the edge of the crater. The first stage of growth appears to have been largely exogenous, with the marginal rampart being built by repeated overflow and quenching of numerous short lava tubes or "pillows."

A second major influx of magma appears to have gently domed and stretched the now-solidified upper surface of the delta, forming the radial fractures that extend away from the crater rim. The upper surface of this new magma filling was quenched against the water-saturated pillowed unit above, forming the aphanitic vesicular basalt recovered in the drill core. As this endogenic phase of uplift and stretching continued, lava broke out on the unsupported northeast flank of Serocki. This breach developed into a major flow channel, and lava escaped to lower levels, forming a new lava delta slightly to the east and north of Serocki (Figs. 1 and 2). This second delta also ultimately collapsed, as indicated by the shallow depression in its summit (Fig. 2). As the flow through the breached flank of Serocki increased in volume and velocity, portions of the flank above the emerging flow began to collapse, forming the arcuate fractures and stepped terraces on the northeast flank (Figs. 5A and -B).

The location of the least-evolved basalts at the base of Serocki's eastern scarp and within the crater and its walls suggests that the early eruptions in this area consisted of a lava similar in composition to those at Site 649. This was followed by eruption of sparsely olivine and plagioclase phyric pillow lavas that were more evolved than the early eruptives, and were probably derived by fractionation within the magma chamber. The trace element data, together with experimental work on similar glasses (Toomey et al., 1987), suggest that the fractionation scheme most likely involved some early-stage clinopyroxene. Such a fractionation scheme would require stabilization of clinopyroxene at elevated pressure. Possible phase equilibria relations in Serocki lavas are discussed by Grove et al. (this volume).

Alvin Sample 1690-16A collected from talus at the bottom of the crater suggests that some of the late-stage eruptives were more highly evolved than the basalts that comprise the bulk of the volcanic pile. These more evolved basalts may have formed a cap which later collapsed as lava drained from the underlying pond. A ridge extending north from this delta, as well as a crater-like depression in the center of this delta, show that there was additional collapse and extension of the flow to the north, beyond our area of detailed study.

If Serocki "Volcano" is typical of the string of axial volcano-like features seen in this southern spreading cell, then crustal accretion along this segment of the Mid-Atlantic Ridge appears to occur mainly by successive magmatic pulses with a rate and volume especially conducive to construction of individual dammed lava ponds, followed by post-eruptive fissuring and faulting. Geochemically, the ma- 
Table 3. Major and trace element analyses of basalts and peridotites from Sites 669 and 670 . All analyses completed at University of Massachusetts. Major element analyses in wt\%: trace element concentration in ppm.

\begin{tabular}{|c|c|c|c|c|c|c|c|c|c|c|c|c|c|}
\hline & \multicolumn{2}{|c|}{ Basalts } & \multicolumn{11}{|c|}{ Peridotites } \\
\hline & $\begin{array}{c}6691-1 \\
11-13 \mathrm{~cm}\end{array}$ & $\begin{array}{l}6703-1 \\
0-5 \mathrm{~cm}\end{array}$ & $\begin{array}{c}6705-1 \\
8-11 \mathrm{~cm}\end{array}$ & $\begin{array}{r}6705-1 \\
125-127\end{array}$ & $\begin{array}{c}6705-2 \\
50-52 \mathrm{~cm}\end{array}$ & $\begin{array}{c}6705-2 \\
78-80 \mathrm{~cm}\end{array}$ & $\begin{array}{c}6705-2 \\
87-89 \mathrm{~cm}\end{array}$ & $\begin{array}{c}6705-2 \\
118-120 \mathrm{~cm}\end{array}$ & $\begin{array}{c}6705-2 \\
139-142 \mathrm{~cm}\end{array}$ & $\begin{array}{c}6706-1 \\
25-27 \mathrm{~cm}\end{array}$ & $\begin{array}{l}6707-1 \\
2-4 \mathrm{~cm}\end{array}$ & $\begin{array}{c}6708-1 \\
12-14 \mathrm{~cm}\end{array}$ & $\begin{array}{l}6709-1 \\
4-8 \mathrm{~cm}\end{array}$ \\
\hline $\mathrm{SiO}_{2}$ & 50.57 & 49.04 & 43.65 & 41.27 & 46.05 & 42.02 & 43.67 & 43.71 & 43.51 & 44.27 & 42.12 & 43.81 & 46.31 \\
\hline $\mathrm{TiO}_{2}$ & 1.93 & 1.11 & 0.02 & 0.01 & 0.00 & 0.01 & 0.02 & 0.02 & 0.02 & 0.02 & 0.00 & 0.02 & 0.02 \\
\hline $\mathrm{Al}_{2} \mathrm{O}_{3}$ & 15.18 & 18.93 & 2.03 & 0.53 & 0.30 & 0.76 & 1.86 & 1.59 & 1.04 & 2.14 & 1.15 & 1.46 & 1.95 \\
\hline $\mathrm{FeO}^{*}$ & 10.66 & 7.72 & 7.97 & 8.11 & 6.99 & 9.10 & 7.70 & 8.21 & 8.20 & 7.64 & 8.67 & 7.88 & 8.12 \\
\hline $\mathrm{MnO}$ & 0.19 & 0.14 & 0.13 & 0.14 & 0.09 & 0.13 & 0.12 & 0.13 & 0.13 & 0.14 & 0.12 & 0.12 & 0.13 \\
\hline $\mathrm{MgO}$ & 7.35 & 7.77 & 43.04 & 48.41 & 46.11 & 47.26 & 45.39 & 44.07 & 45.54 & 42.29 & 46.33 & 43.93 & 41.90 \\
\hline $\mathrm{CaO}$ & 10.76 & 12.44 & 1.77 & 0.01 & 0.03 & 0.15 & 0.45 & 1.06 & 0.75 & 2.14 & 0.25 & 1.62 & 0.79 \\
\hline $\mathrm{Na}_{2} \mathrm{O}$ & 3.14 & 2.66 & 0.00 & 0.02 & 0.03 & 0.05 & 0.06 & 0.02 & 0.01 & 0.08 & 0.08 & 0.09 & 0.01 \\
\hline $\mathrm{K}_{2} \mathrm{O}$ & 0.24 & 0.18 & 0.00 & 0.01 & 0.01 & 0.01 & 0.02 & 0.02 & 0.01 & 0.01 & 0.01 & 0.02 & 0.01 \\
\hline $\mathrm{P}_{2} \mathrm{O}_{5}$ & 0.20 & 0.10 & 0.00 & 0.00 & 0.02 & 0.00 & 0.00 & 0.00 & 0.00 & 0.00 & 0.00 & 0.00 & 0.00 \\
\hline Sum & 100.22 & 100.09 & 98.61 & 98.51 & 99.63 & 99.49 & 99.29 & 98.84 & 99.21 & 98.73 & 98.73 & 98.95 & 99.24 \\
\hline $\mathrm{Rb}$ & - & 2.3 & $<0.1$ & $<0.1$ & $<0.1$ & $<0.1$ & $<0.1$ & $<0.1$ & $<0.1$ & $<0.1$ & $<0.1$ & $<0.1$ & 0.1 \\
\hline V & - & 195 & 42 & 7 & 3 & 17 & 42 & 36 & 27 & 54 & 21 & 42 & 46 \\
\hline $\mathrm{Cr}$ & - & 314 & 2189 & 1065 & 150 & 1285 & 2268 & 2151 & 1421 & 2729 & 1831 & 2308 & 2355 \\
\hline $\mathrm{Ni}$ & - & 113 & 2013 & 1959 & 2130 & 2337 & 2031 & 1950 & 2082 & 1928 & 2235 & 1991 & 1848 \\
\hline $\mathrm{Zn}$ & - & 69 & 46 & 21 & 25 & 34 & 30 & 36 & 54 & 46 & 45 & 41 & 36 \\
\hline $\mathrm{Sr}$ & - & 139 & 0.9 & 0.1 & 1.3 & 0.2 & 0.8 & 1.4 & 1.0 & 1.1 & 1.5 & 1.1 & 1.0 \\
\hline $\mathrm{Y}$ & - & 24 & 0.7 & 0.2 & 0.2 & 0.4 & 0.6 & 0.6 & 0.4 & 1.1 & $<0.1$ & 0.8 & 0.7 \\
\hline $\mathrm{Zr}$ & - & 78 & $<0.1$ & 0.2 & $<0.1$ & $<0.1$ & $<0.1$ & 0.2 & 0.2 & $<0.1$ & 0.1 & $<0.1$ & 0.5 \\
\hline $\mathrm{Nb}$ & - & 2 & $<0.1$ & 0.1 & 0.1 & 0.2 & $<0.1$ & 0.1 & $<0.1$ & $<0.1$ & 0.7 & 0.6 & 0.1 \\
\hline $\mathrm{Ga}$ & - & 16 & 2.3 & 1.5 & 1.1 & 1.8 & 1.9 & 1.9 & 1.7 & 1.9 & 2.2 & 2.1 & 2.3 \\
\hline
\end{tabular}

Table 4. Microprobe analyses of glasses from samples collected during Alvin dive 1690 on Serocki Volcano. All analyses completed at Smithsonian Institution; sample locations in Figure 4. Major element analyses in wt\%.

\begin{tabular}{|c|c|c|c|c|c|c|c|c|c|c|c|c|c|c|c|c|c|c|c|c|c|c|}
\hline & 1 & 2 & 3 & 4 & 5 & 8 & 9 & 10 & 11 & 12 & 13 & 14 & 15 & $16 \mathrm{~A}$ & 17 & $18 \mathrm{~A}$ & $18 \mathrm{~B}$ & 19 & 20 & 21 & 22 & 23 \\
\hline $\mathrm{SiO}_{2}$ & 50.44 & 50.12 & 50.34 & 50.30 & 49.85 & 50.10 & 49.83 & 49.48 & 49.95 & 49.83 & 50.06 & 50.24 & 49.51 & 50.62 & 50.21 & 49.76 & 50.42 & 49.98 & 49.93 & 49.94 & 49.63 & 50.05 \\
\hline $\mathrm{TiO}_{2}$ & 1.67 & 1.78 & 1.73 & 1.80 & 1.47 & 1.62 & 1.67 & 1.65 & 1.70 & 1.71 & 1.70 & 1.75 & 1.78 & 1.91 & 1.42 & 1.45 & 1.47 & 1.58 & 1.73 & 1.73 & 1.74 & 1.72 \\
\hline $\mathrm{Al}_{2} \mathrm{O}_{3}$ & 15.64 & 15.88 & 15.90 & 15.61 & 16.46 & 16.01 & 15.84 & 15.87 & 16.02 & 15.81 & 15.74 & 15.55 & 15.64 & 14.71 & 16.40 & 16.34 & 16.36 & 16.01 & 15.73 & 15.90 & 15.86 & 15.81 \\
\hline $\mathrm{FeO}^{*}$ & 10.25 & 9.98 & 10.03 & 10.22 & 8.72 & 9.90 & 9.65 & 10.10 & 10.28 & 10.04 & 10.00 & 9.97 & 10.07 & 10.72 & 9.29 & 9.20 & 9.06 & 9.66 & 10.42 & 10.26 & 10.13 & 10.35 \\
\hline $\mathrm{MgO}$ & 7.28 & 7.33 & 7.30 & 7.34 & 7.68 & 7.71 & 7.57 & 7.64 & 7.54 & 7.35 & 7.45 & 7.30 & 7.35 & 6.75 & 8.16 & 8.09 & 7.93 & 7.75 & 7.54 & 7.38 & 7.31 & 7.47 \\
\hline $\mathrm{CaO}$ & 11.13 & 11.08 & 11.10 & 11.18 & 11.55 & 11.22 & 11.25 & 11.15 & 11.13 & 11.19 & 11.18 & 11.26 & 11.03 & 11.22 & 11.48 & 11.47 & 11.54 & 11.28 & 11.01 & 11.06 & 11.07 & 11.10 \\
\hline $\mathrm{Na}_{2} \mathrm{O}$ & 2.93 & 2.97 & 2.96 & 2.93 & 2.83 & 2.87 & 2.97 & 2.98 & 3.02 & 2.93 & 2.92 & 2.98 & 3.05 & 3.06 & 2.85 & 2.82 & 2.79 & 2.91 & 2.92 & 2.98 & 2.92 & 2.96 \\
\hline $\mathrm{K}_{2} \mathrm{O}$ & 0.13 & 0.13 & 0.14 & 0.14 & 0.25 & 0.13 & 0.12 & 0.14 & 0.13 & 0.16 & 0.15 & 0.14 & 0.15 & 0.16 & 0.13 & 0.12 & 0.12 & 0.13 & 0.15 & 0.15 & 0.14 & 0.16 \\
\hline $\mathrm{P}_{2} \mathrm{O}_{5}$ & 0.17 & 0.17 & 0.17 & 0.16 & 0.15 & 0.13 & 0.16 & 0.22 & 0.18 & 0.17 & 0.18 & 0.18 & 0.21 & 0.20 & 0.16 & 0.14 & 0.16 & 0.16 & 0.21 & 0.18 & 0.16 & 0.20 \\
\hline Total & 99.64 & 99.44 & 99.67 & 99.68 & 98.96 & 99.69 & 99.06 & 99.23 & 99.95 & 99.19 & 99.38 & 99.37 & 98.79 & 99.35 & 100.10 & 99.39 & 99.85 & 99.46 & 99.64 & 99.58 & 98.96 & 99.82 \\
\hline
\end{tabular}



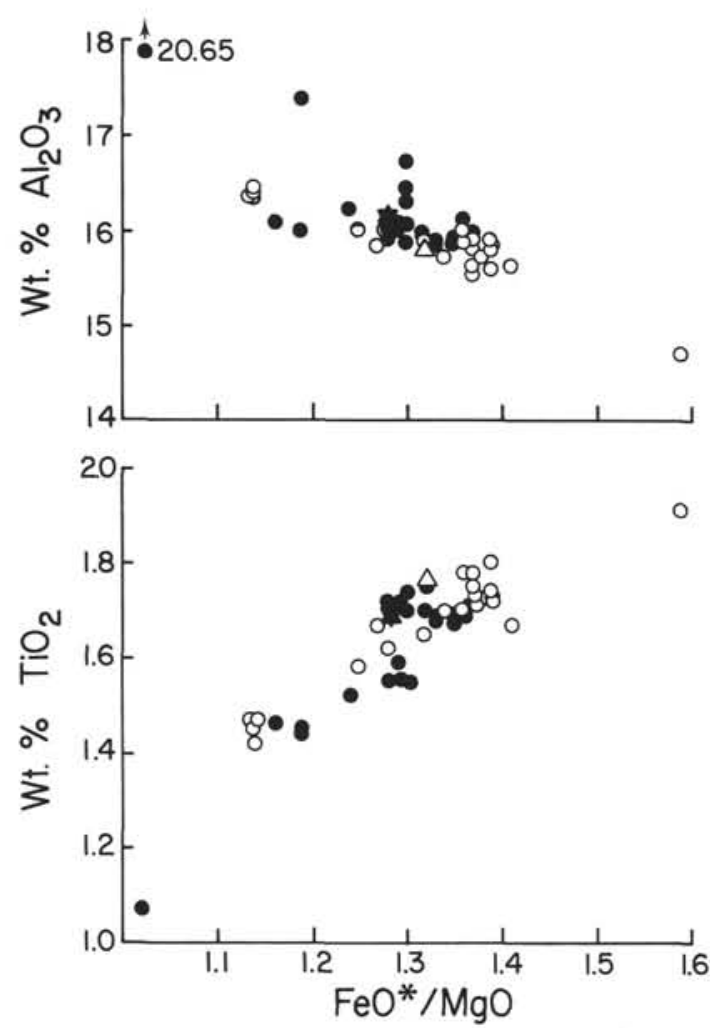

Figure 6. Variation diagrams for $\mathrm{TiO}_{2}$ and $\mathrm{Al}_{2} \mathrm{O}_{3}$ concentrations with $\mathrm{FeO}^{*} / \mathrm{MgO}$ ratios in both glasses and whole rock samples. Averages for glasses $(\Delta)$ and shipboard whole rock analyses $(\boldsymbol{\nabla})$ of Hole 648B samples are from Detrick, Honnorez, Bryan, Juteau, et al. (1988). (A) denotes average of Hole $648 \mathrm{~B}$ whole rock analyses presented here. Alvin glasses $(O)$ and whole rock $(\bullet)$ analyses are presented in this paper.

jor unit of Serocki Volcano is most similar to the AII92 glasses dredged on the east side of the rift valley about $10 \mathrm{~km}$ to the north. This is consistent with the magnetic data that suggest the extrusive rift, of which Serocki is a part, extends obliquely across the valley and at least that far north (Schulz et al., in press). In addition, the Serocki high- $\mathrm{Al}_{2} \mathrm{O}_{3}$ magma type is similar to basalt recovered from Sites 395 and 396 , which are about 7 and $10 \mathrm{~m} . y$. old, respectively. This suggests that eruption of this type of lava has occurred intermittently over a long period of time, and may indicate that the source of magma that produced these basalts in the southern spreading cell is of a relatively long temporal and large spatial extent.

There may also be a close relation between the southern and northern spreading cells in terms of the geochemical nature of their volcanism. The similarity between the lowest unit of Serocki Volcano, the G2 chemical subgroup at Site 396, and the glasses from Site 649 (the Snake Pit hydrothermal area in the northern spreading cell), suggests that a source similar to that found in the southern spreading cell also feeds the rift at Site 649. Finally, the similarities in geochemistry contrast with the eruptive styles of the two rift systems: a well-defined rift to the north, with less morphologic definition of individual centers, and more distinct aligned lava cones to the south, suggesting a more pulsational style of effusion.

\section{ACKNOWLEDGMENTS}

We would like to thank T. O'Hearn for providing the glass data, and B. Schroeder, M. Sulanowska, and the late D. Bankston
(WHOI), and Joel Sparks and Doris Hills (U. Mass.) for help with the analyses. Discussions with T. Grove, S. Komor, and J. Casey have been especially useful during preparation of this manuscript. Critical reviews and comments by C. Mevel and J. Karson greatly improved this manuscript. This work was supported by grants from USSAC through the Texas A\&M Research Foundation to $\mathrm{S}$. Humphris, W. B. Bryan, and L. K. Autio, and by NSF grants OCE85-11979 and OCE85-10847. This is WHOI Contribution Number 6821 .

\section{REFERENCES}

Autio, L. K., and Rhodes, J. M., 1983. Costa Rica rift zone basalts: geochemical and experimental data from a possible example of multistage melting. In Cann, J. R., Langseth, M. G., Honnorez, J., Von Herzen, R. P., White, S. M., et al., Init. Repts. DSDP, 69: Washington (U.S. Govt. Printing Office), 729-745.

Brown, J. R., and Karson, J. A., in press. Variations in axial processes on the Mid-Atlantic Ridge: the neovolcanic zone of the Mark area. Mar. Geophys. Res.

Bryan, W. B., and Dick, H.J.B., 1982. Contrasted abyssal basalt liquidus trends: evidence for mantle major element heterogeneity. Earth Planet. Sci. Lett., 58:15-26.

Bryan, W. B., Thompson, G., and Ludden, J. N., 1981. Compositional variation in normal MORB from $22-25^{\circ} \mathrm{N}$ : Mid-Atlantic Ridge and Kane Fracture Zone. J. Geophys. Res., 86:1181511836.

Detrick, R. S., and Purdy, G. M., 1980. The crustal structure of the Kane Fracture Zone from seismic refraction studies. J. Geophys. Res., 85:3759-3778.

Detrick, R. S., Fox, P. J., Kastens, K. A., Ryan, W.B.F., Mayer, L., and Karson, J. A., 1984. Sea Beam survey of the Kane Fracture Zone and the adjacent Mid-Atlantic Ridge rift valley. EOS, 65:1006.

Detrick, R., Honnorez, J., Bryan, W. B., Juteau, T., et al., 1988. Proc. ODP, Init. Repts., 106/109: College Station, TX (Ocean Drilling Program).

Grove, T. L., and Bryan, W. B., 1983. Fractionation of pyroxenephyric MORB at low pressure: an experimental study. Contr. Mineral. Petrol., 84:293-309.

Guest, J. E., Wood, C., and Greeley, R., 1984. Lava tubes, terraces and megatumuli on the 1614-1624 pahoehoe lava flow field, Mount Etna, Sicily. Bull. Volcanol., 47:635-648.

Holcomb, R. T., Peterson, D. W., and Tilling, R. I., 1974. Recent landforms at Kilauea Volcano. In: Geologic Guide to the Island of Hawaii. NASA CR, 152416:50-86.

Karson, J. A., and Dick, H.J.B., 1983. Tectonics of ridge-transform intersections at the Kane Fracture Zone. Mar. Geophys. Res., 6:51-98.

Karson, J. A., Thompson, G., Humphris, S. E., Edmond, J. M., Bryan, W. B., Brown, J. R., Winters, A. T., Pockalny, R. A., Casey, J. R., Campbell, A. C., Klinkhammer, G., Palmer, M. R., Kinzler, R. J., and Sulanowska, M. M., 1987. Along-axis variations in seafloor spreading in the MARK area. Nature, 328:681-685.

Kong, L.S.L., Detrick, R. S., Fox, P. J., Mayer, L. A., and Ryan, W.B.F., in press. The morphology and tectonics of the MARK area from Sea Beam and SeaMARC I observations (Mid-Atlantic Ridge $23^{\circ} \mathrm{N}$ ). Mar. Geophys. Res.

Mayer, L. A., Ryan, W.B.F., Detrick, R. S., Fox, P. J., Kong, L. and Manchester, K., 1985. Structure and tectonics of the MidAtlantic Ridge south of the Kane Fracture Zone based on SeaMARC I and Sea Beam site surveys. EOS, 66:1092.

Melson, W. G., 1977. Microprobe analysis of basalt glass from the world's ocean. Smithsonian Contrib. Earth Sci., 19:198-205.

, 1978. Chemical stratigraphy of Leg 45 basalts: electron probe analyses of glasses. In Melson, W. G., and Rabinowitz, P. D., et al. Init. Repts. DSDP, 45: Washington (U.S. Govt. Printing Office), 507-512.

Melson, W. G., Thompson, G. and Van Andel, T. H., 1968. Volcanism and metamorphism in the Mid-Atlantic Ridge, $22^{\circ} \mathrm{N}$. latitude. J. Geophys. Res., 73:5925-5941.

Melson, W. G. and O'Hearn, T., 1979. Basaltic glass erupted along the Mid-Atlantic Ridge between $0-37^{\circ} \mathrm{N}$ : relationships between composition and latitude. In Talwani, M., et al. (Eds.): Deep 
Drilling Results in the Atlantic Ocean. Proceedings of Second Maurice Ewing Symposium, 249-261.

Miyashiro, A., Shido, F., and Ewing, M., 1969. Composition and origin of serpentinites from the Mid-Atlantic Ridge, 24 and $30^{\circ} \mathrm{N}$. Contrib. Mineral. Petrol., 32:38-52.

1970. Petrologic models for the Mid-Atlantic Ridge. Deep Sea Res., 17:109-123.

Natland, J., Bougault, H., Fujii, T., Graham, A. L., Melson, W. G., Prosser, E., Rhodes, J. M., and Zolotarev, B., 1978. Chemical data for Sites 395 and 396: analytical procedures and comparisons of interlaboratory standards. In Melson, W. G., Rabinowitz, P. D. et al., Init. Repts. DSDP, 45: Washington (U.S. Govt. Printing Office), 681-705.

Purdy, G. M., and Detrick, R. S., 1986. The crustal structure of the Mid-Atlantic Ridge at $23^{\circ} \mathrm{N}$ from seismic refraction studies. $J$. Geophys. Res., 91:3739-3762.

Purdy, G. M., Rabinowitz, P. D., and Schouten, H., 1978. The Mid-Atlantic Ridge at $23^{\circ} \mathrm{N}$ : bathymetry and magnetics. In Melson, W. G., Rabinowitz, P. D. et al., Init. Repts. DSDP, 45: Washington (U.S. Govt. Printing Office), 119-128.

Reid, J. B., Steig, E., and Bryan, W. B., in press. Major element evolution of basaltic magmas: a comparison of the information in CMAS and ALFE projections. Contrib. Mineral. Petrol.
Schroeder, B., Thompson, G., Sulanowska, M., and Ludden, J. N., 1980. Analysis of geologic materials using an automated X-ray fluorescence system. X-Ray Spectr., 9:198-205.

Schulz, N. J., Detrick, R. S., and Miller, S. P., in press. Two and three dimensional inversions of magnetic anomalies in the MARK area. Mar. Geophys. Res.

Toomey, D. R., Solomon, S. C., and Purdy. G. M., 1988. Microearthquakes beneath the median valley of the Mid-Atlantic Ridge near $23^{\circ} \mathrm{N}$ : tomography and tectonics. J. Geophys. Res., 93:9093-9112.

Toomey, D. R., Grove, T. L., and Bryan, W. B., 1987. Experimental petrology of normal MORB near the Kane Fracture Zone: 22$25^{\circ}$ N, Mid-Atlantic Ridge. Contrib. Mineral. Petrol., 96:121-139.

Van Andel, T. J., and Bowin, C. O., 1968. Mid-Atlantic Ridge between $22^{\circ}$ and $23^{\circ}$ north latitude and the tectonics of mid-ocean rises. J. Geophys. Res., 73:1279-1298.

Date of initial receipt: 3 June 1988

Date of acceptance: 20 April 1989

Ms 106/109B-124

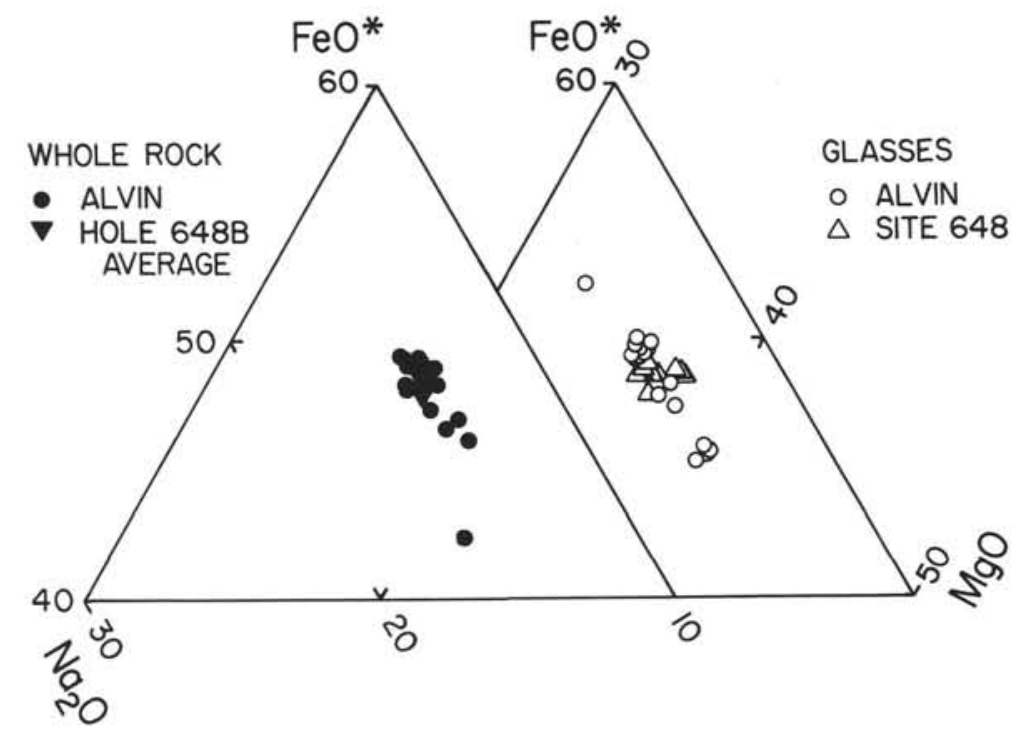

Figure 7. $\mathrm{Na}_{2} \mathrm{O}-\mathrm{FeO}^{*}-\mathrm{MgO}$ diagram for glasses and whole rocks from Serocki Volcano. Averages of glasses from Site 648 are from Detrick, Honnorez, Bryan, Juteau, et al. (1988). 


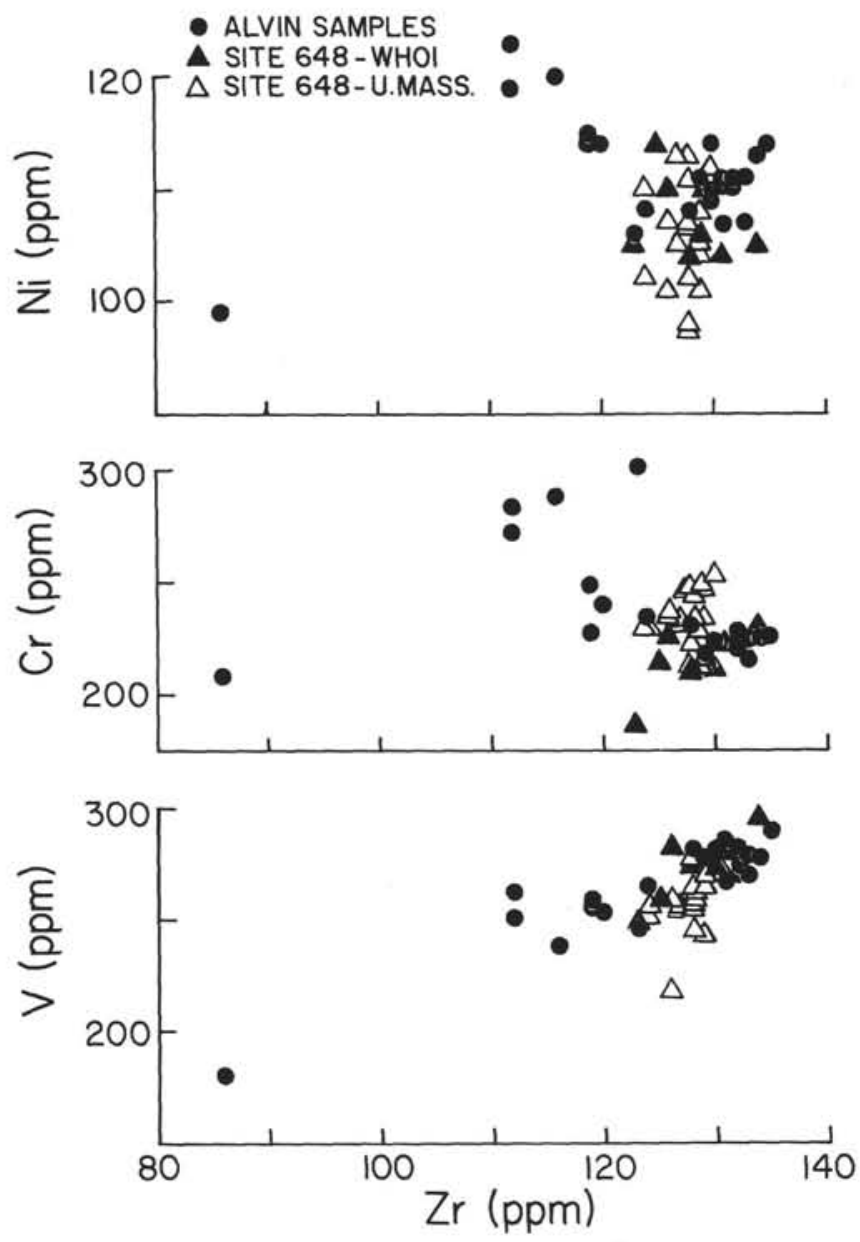

Figure 8. Trace element concentrations vs. $\mathrm{Zr}$ concentrations in whole rocks from Serocki Volcano.

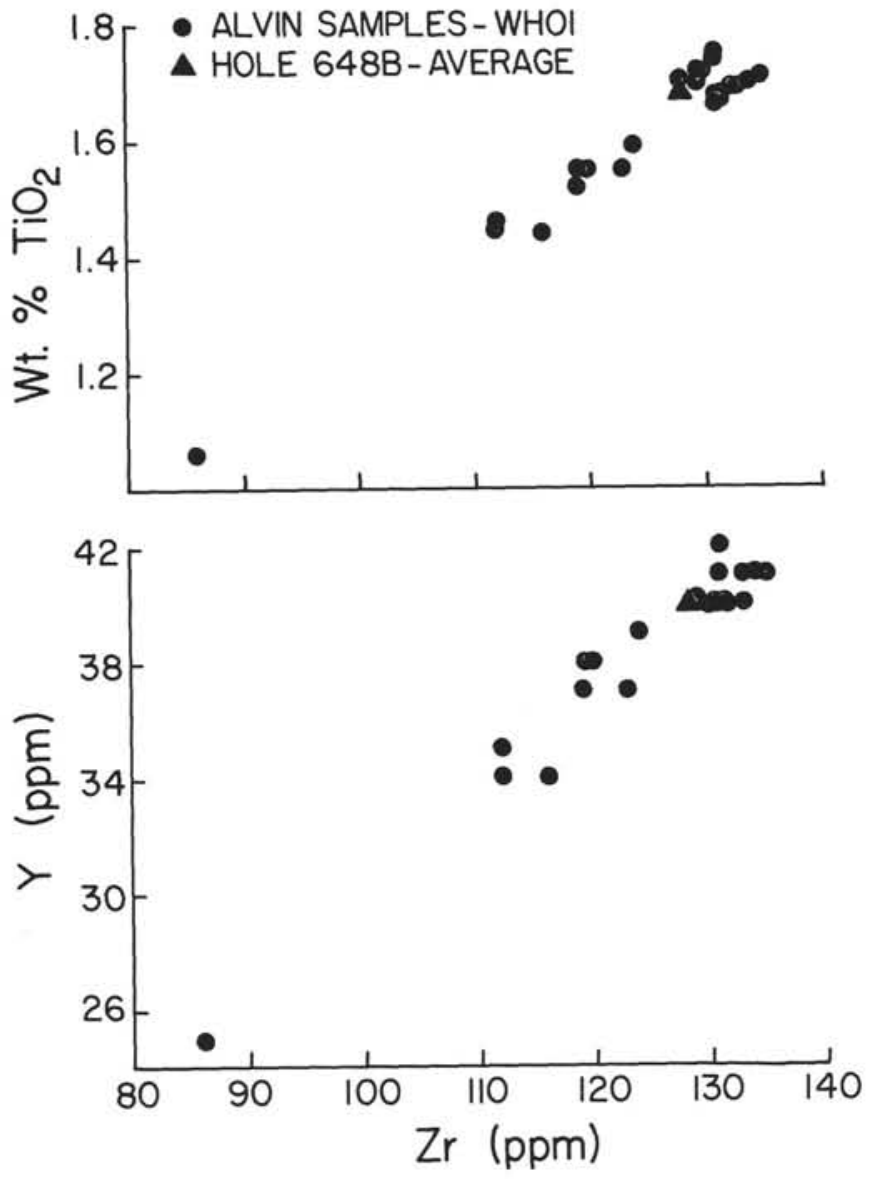

Figure 9. Variation diagrams for $\mathrm{Y}$ and $\mathrm{TiO}_{2}$ with $\mathrm{Zr}$ concentrations for Alvin samples. Also shown is the average for Site 648 drilled rocks.

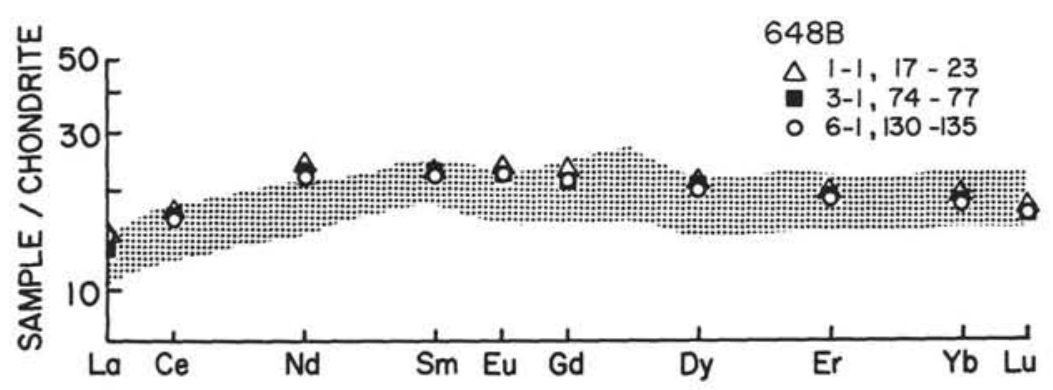

Figure 10. Chondrite-normalized REE patterns for three selected samples from Hole 648B. The shaded area shows the field of four samples from cruises AII 78 and AII92 taken from the Mid-Atlantic Ridge rift valley at about $23^{\circ} \mathrm{N}$ (Bryan et al., 1981). 


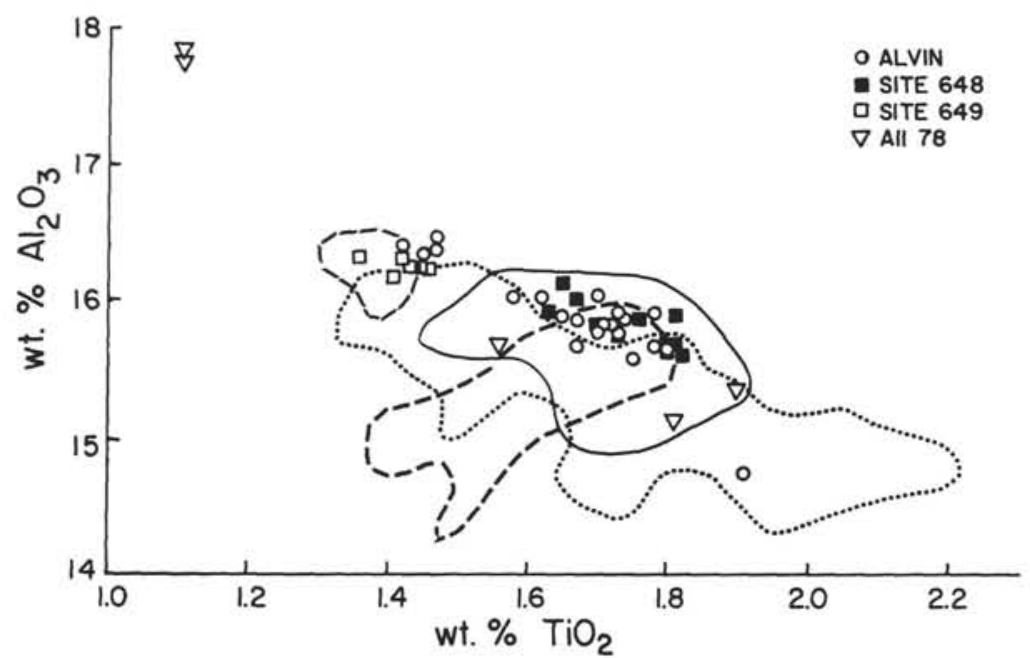

Figure 11. $\mathrm{Al}_{2} \mathrm{O}_{3}-\mathrm{TiO}_{2}$ variation diagram showing glass analyses from Serocki Volcano compared with other glass data from the $22^{\circ}-25^{\circ} \mathrm{N}$ region. The data fields are as follows: AII92 glasses (solid line); Sites 395 and 396 (dashed lines); all other data from dredged glasses (dotted line). The small dashed field represents the G2 chemical subgroup of Melson (1978) and comprises data from glasses found only at Site 396.

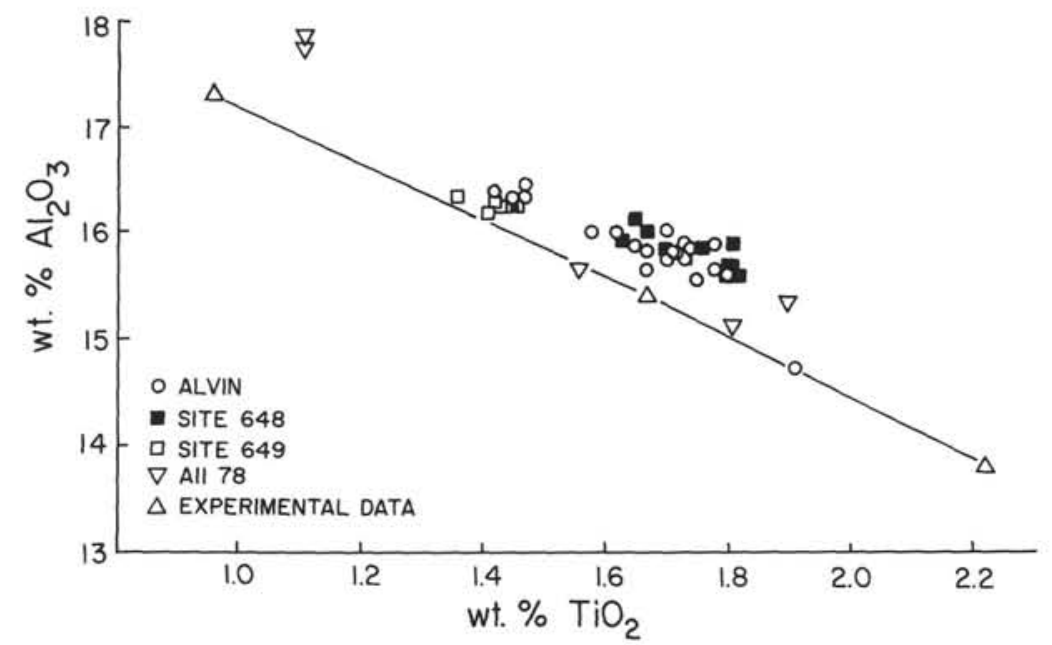

Figure 12. Comparison of glasses from Serocki Volcano and Site 649 with those from AII78 and with low-pressure experimental glasses (Toomey et al., 1987) in $\mathrm{Al}_{2} \mathrm{O}_{3}-\mathrm{TiO}_{2}$ space.

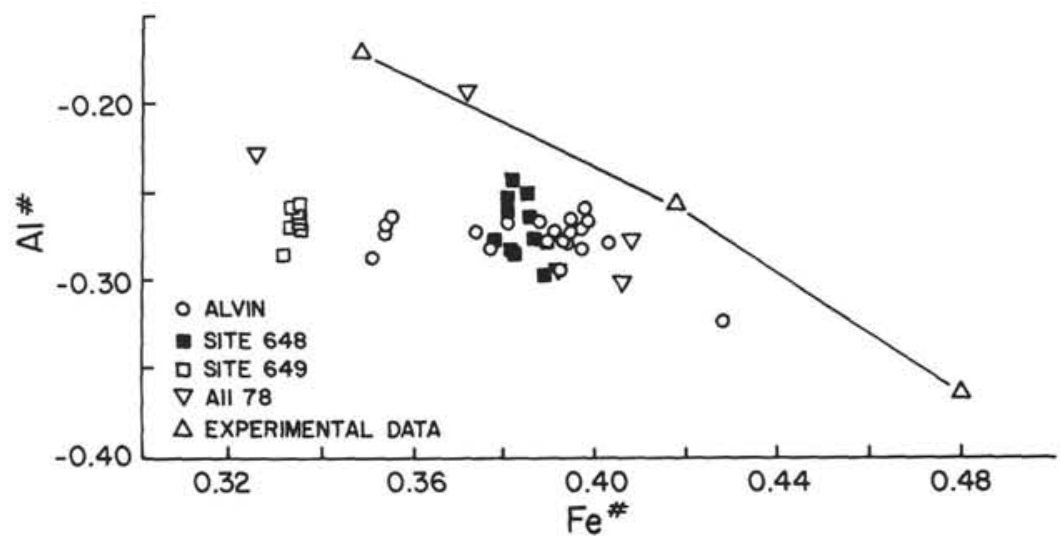

Figure 13. ALFE projection of glasses from Serocki Volcano, Site 649, AII78 and low-pressure experiments. Data as used in Figure 12; see text for discussion of calculation of data points. Note that the Site 649 and the four less-evolved Serocki glasses are distinctly separated in this projection, with the Serocki-Site 649 trend being flatter and lower than the 1-atmosphere trend. 

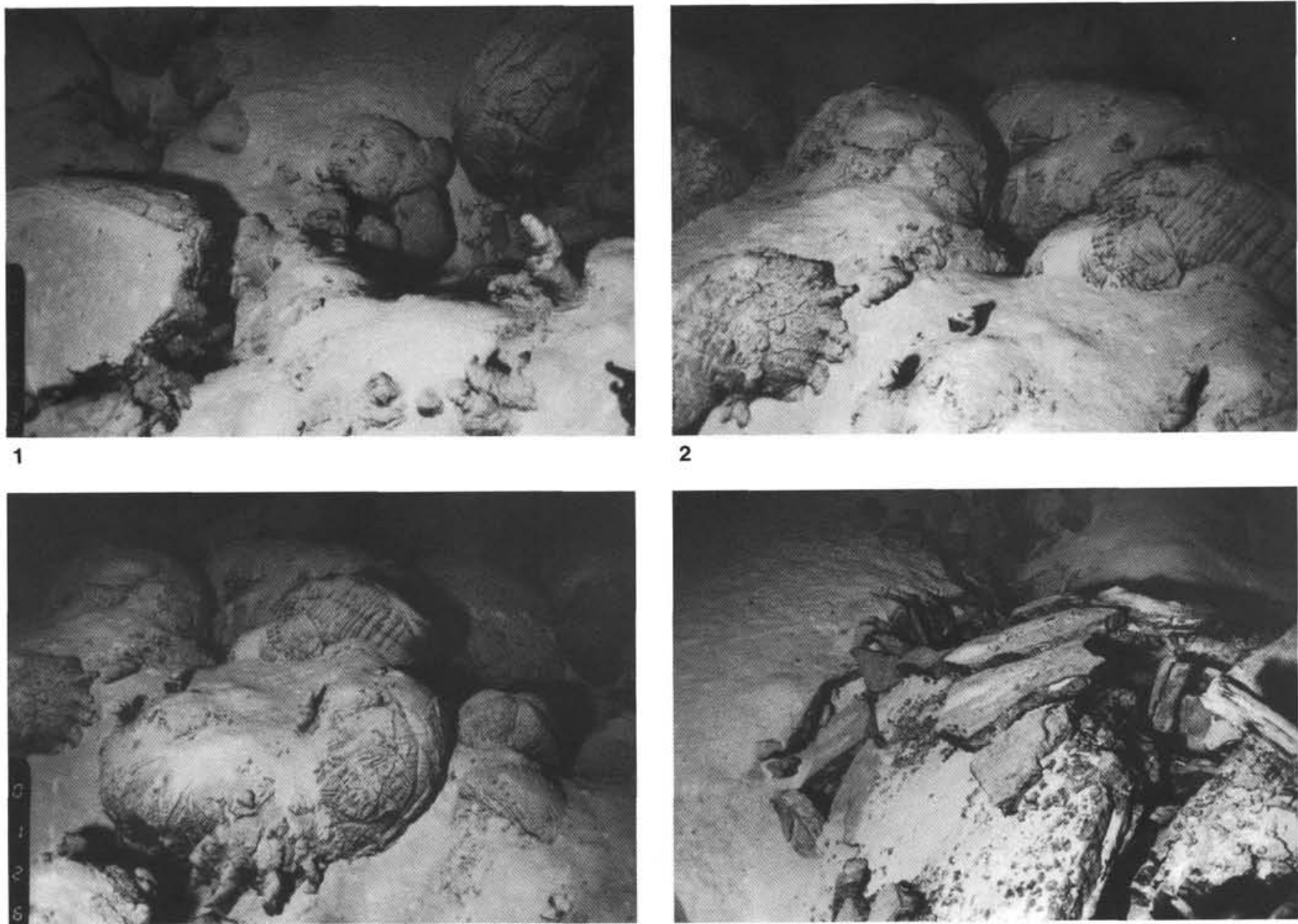

3

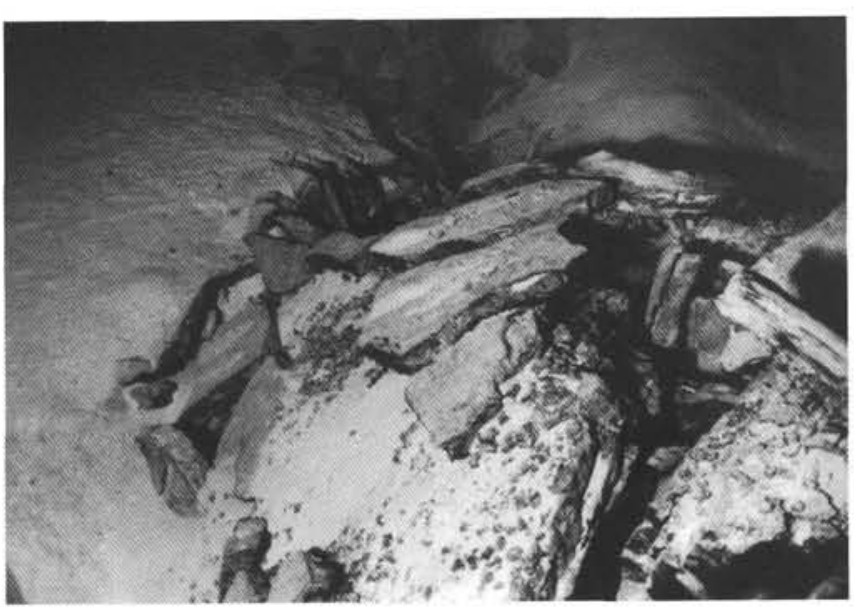

4

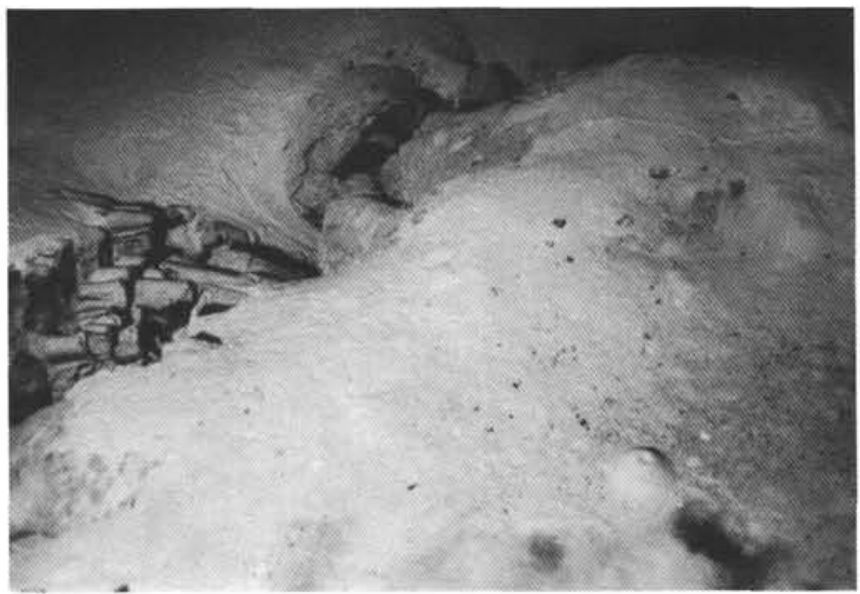

5

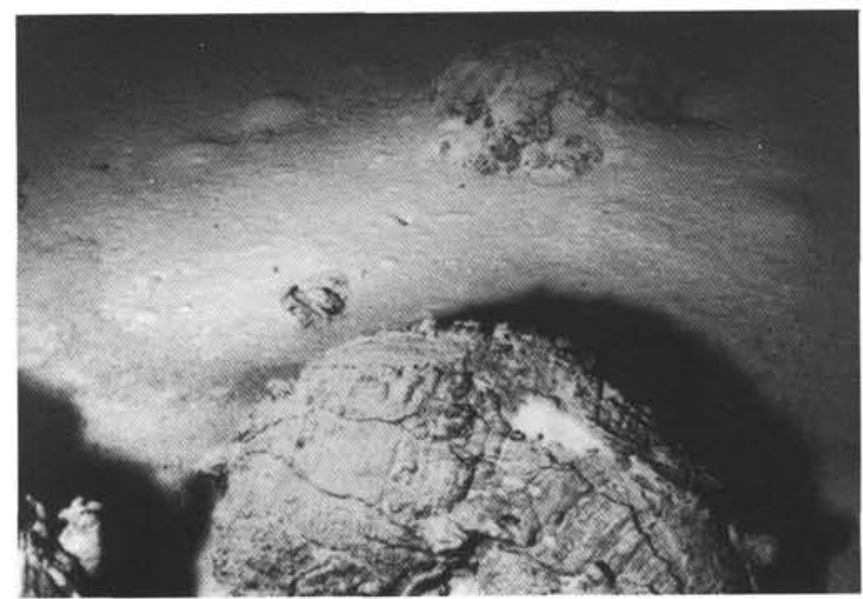

6

Plate 1. Photographs taken from the Alvin of the summit plateau of Serocki Volcano. 1-3. Pillow basalts showing delicate ornamentation and surface striations protruding through the sediment cover. 4. Sheet flow on the northeastern rim of the crater highly disrupted by fissuring. $\mathbf{5}$, $\mathbf{6}$. Summit plateau between Stations 13 and 14 showing moderate sediment cover and north-south fissuring. 


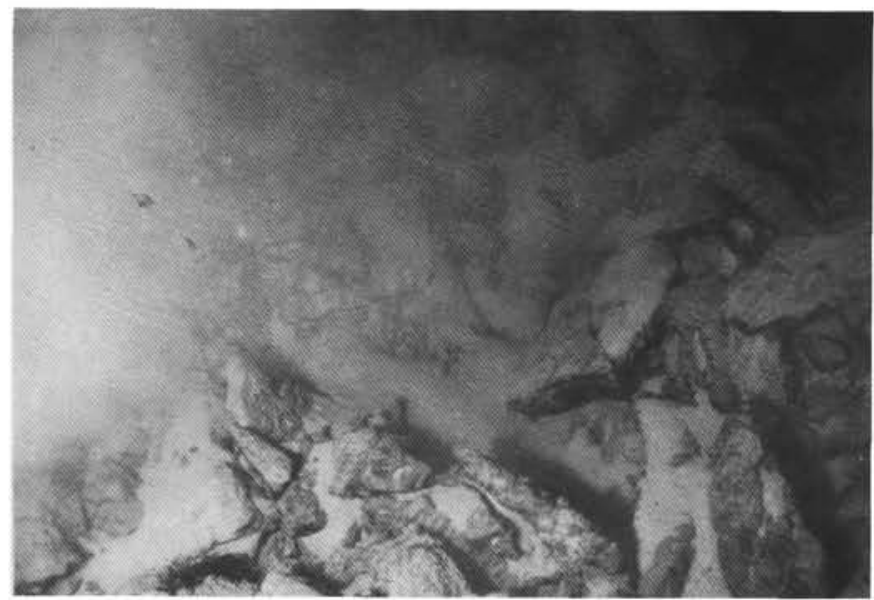

1

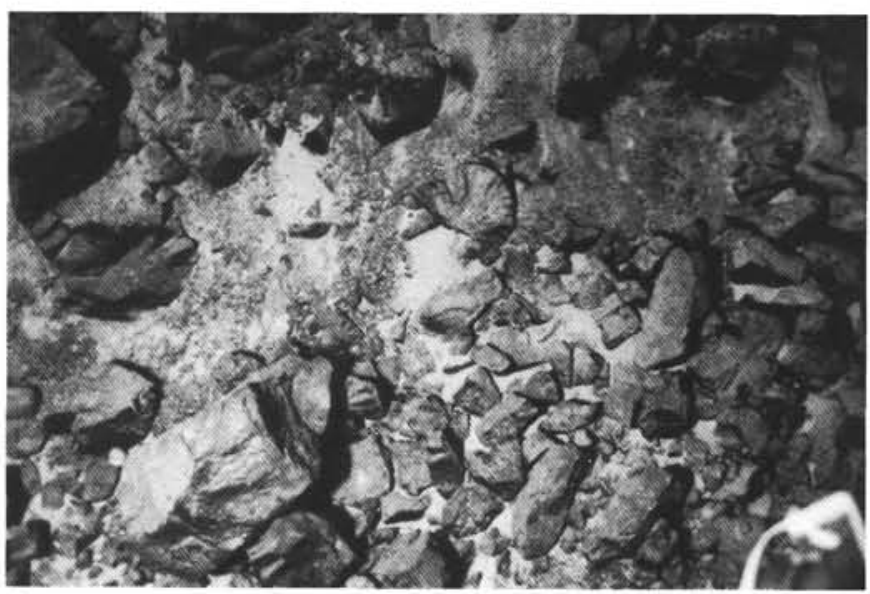

3

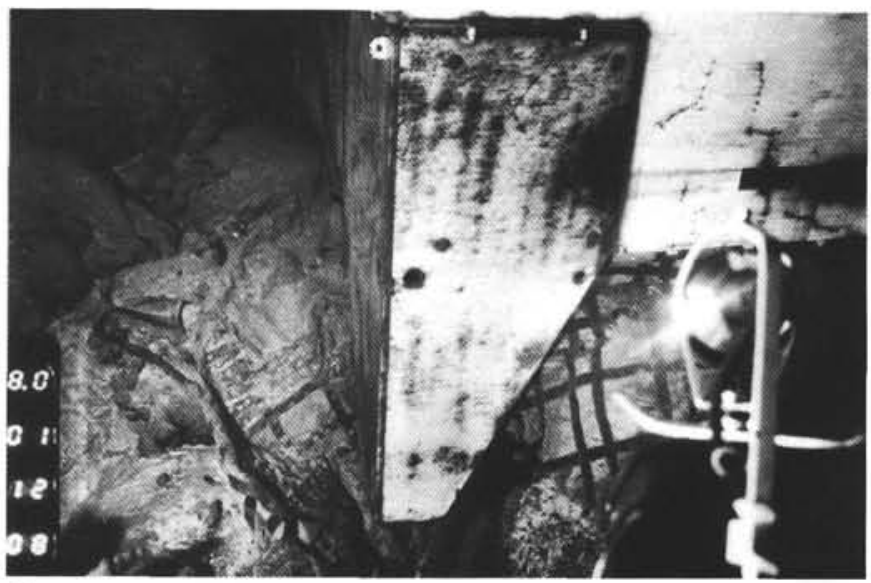

5

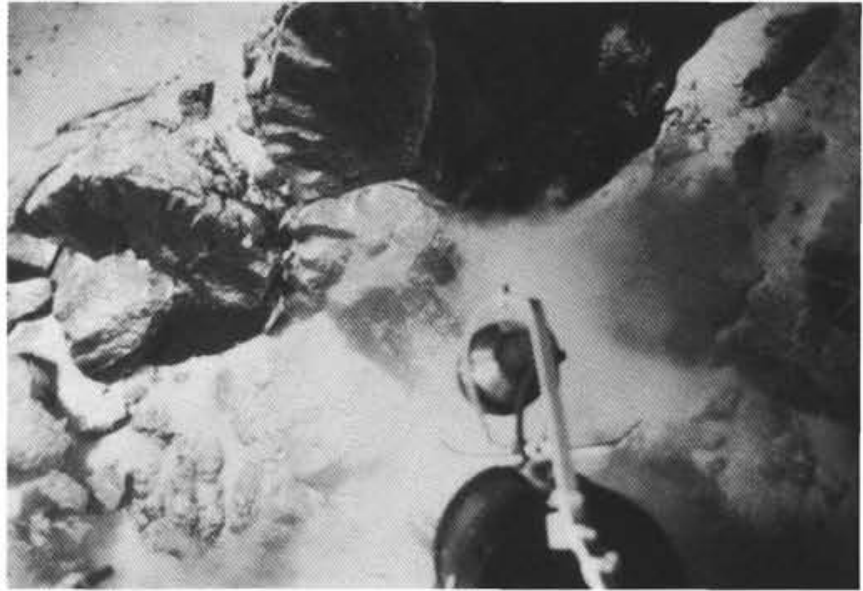

2
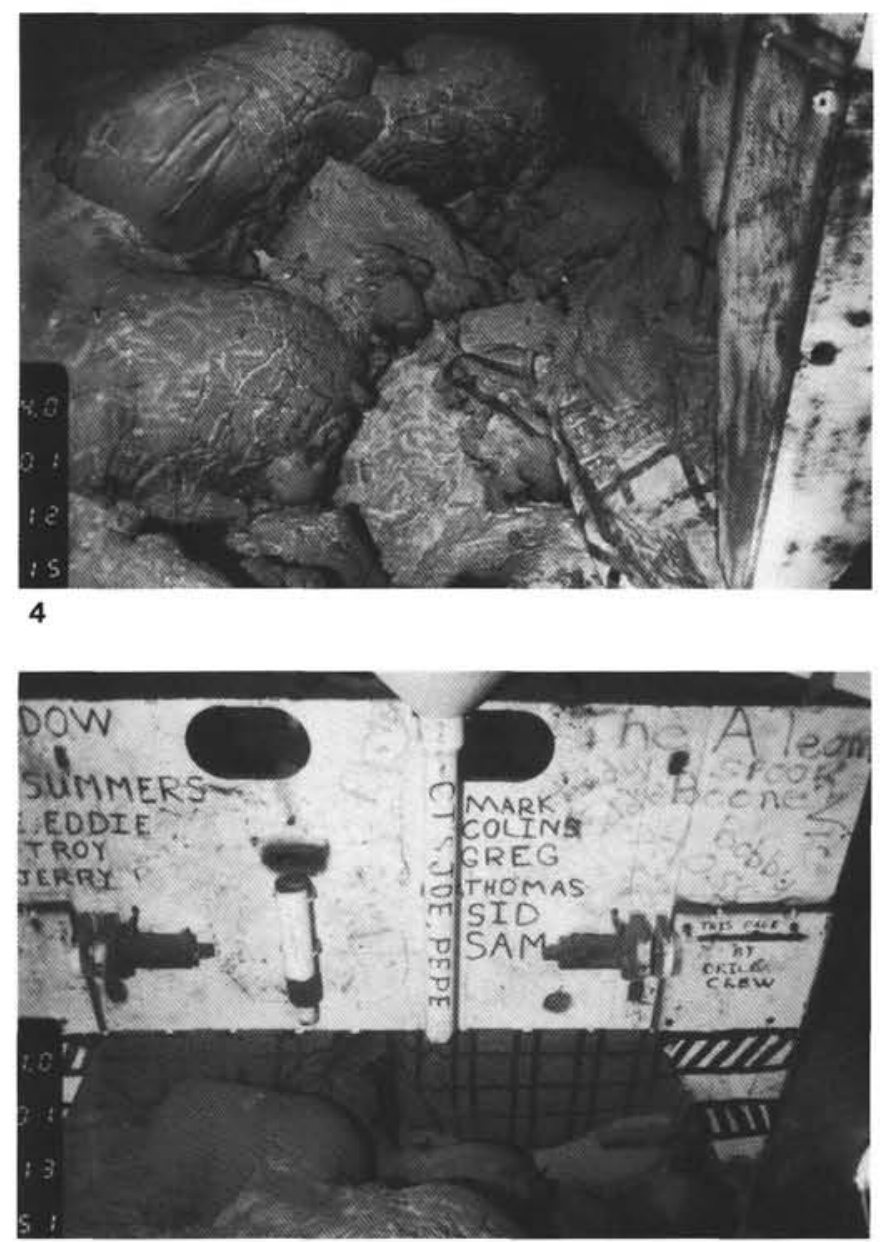

6

Plate 2. Photographs taken from the Alvin of the eastern scarp, crater and Site 648 on Serocki Volcano. 1. Bottom of the crater showing broken sheet flows and pillow lavas. 2. Truncated pillow lavas in western wall of the crater. 3. Eastern side of the Serocki Volcano showing the top of the talus ramp at the base of the vertical scarp of truncated pillow basalt. 4. Pillow lavas, up to $1 \mathrm{~m}$ in diameter, near the hard rock guidebase. Most of the sediment has been disturbed and removed by drilling operations. 5. Leg at the southeast corner of the guidebase suspended over a narrow fissure. 6. Large pillow lavas beneath the guidebase. 